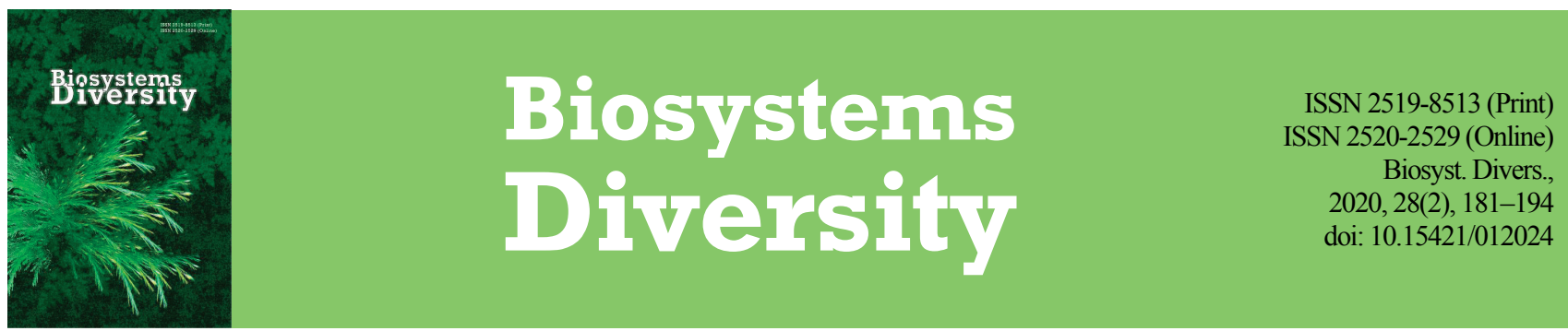

\title{
Applying plant disturbance indicators to reveal the hemeroby of soil macrofauna species
}

\author{
N. V. Yorkina*, S. M. Podorozhniy*, L. G. Velcheva*, Y. V. Honcharenko**, O. V. Zhukov* \\ *Bogdan Khmelnitsky Melitopol State Pedagogical University, Melitopol, Ukraine \\ **H. S. Skovoroda Kharkiv National Pedagogical University, Kharkiv, Ukraine
}

Article info

Received 03.05.2020

Received in revised form

27.05.2020

Accepted 28.05.2020

Bogdan Khmelnitsk

Melitopol State

Pedagogical University

Hetmanska st., 20,

Melitopol, 72318

Ukraine.

Tel.: +38-068-154-15-78

E-mail:nadyayork777@

gmail.com

H. S. Skovoroda

Kharkiv National

Pedagogical University

Valentynivs'ka st., 2,

Kharkiv, 61168, Ukraine

Tel.: +38-068-601-89-40.

E-mail:

janina6962@gmail.com

Yorkina, N. V., Podorozhniy, S. M., Velcheva, L. G., Honcharenko, Y. V., \& Zhukov, O. V. (2020). Applying plant disturbance indicators to reveal the hemeroby of soil macrofauna species. Biosystems Diversity, 28(2), 181-194. doi:10.15421/012024

Hemeroby is an integrated indicator for measuring human impacts on environmental systems. Hemeroby has a complex nature and a variety of mechanisms to affect ecosystems. Hemeroby is often used to assess disturbances in different vegetation types but this concept has seldom been evaluated for animals. The role of the hemeroby gradient in structuring the soil macrofauna community was investigated. The experimental polygon was located in Botanical Garden of the Oles Honchar Dnipro National University (Dnipro City, Ukraine). There were 20 sites within the polygon. On each of them at 105 points samples of soil macrofauna were taken, soil penetration resistance, electrical conductivity of soil, depth of litter, height of grasses were measured. Within each site, a description of the vegetation cover was made. Based on the description of the vegetation, an indication of the level of ecosystem hemeroby within the polygons was conducted. In total, 48,457 invertebrate (Annelida, Arthropoda, and Mollusca) individuals of 6 classes, 13 orders, 50 families and 83 species or parataxonomic units were recorded. Phytoindication reveals that the level of hemeroby within the studied polygons varies from 34.9 to 67.2. The model V and VI from the HOFJO-list were the most optimal model of the species response to hemeroby gradient. The weighted average factor value was used to assess the optimal factor level for the species in a symmetrical bell-shaped response model. The optimal factor level of the hemeroby for the soil macrofauna species ranges from 34.9 to 66.0. Species also differ in degree of specialization to the factor of hemeroby. There was a regular change in the soil macrofauna community size and diversity in the hemeroby gradient. The limiting influence of anthropogenic transformation of the environment on the abundance of soil macrofauna community is clearly marked at the level of hemeroby above average. Species diversity of the community is greatest at moderate hemeroby level. Both relatively little transformed habitats and strongly transformed ones are characterized by lower species richness of the soil macrofauna community. The Shannon index shows a clear upward trend with increasing hemeroby. The Pielou index indicates that the main reason for this trend is an increase in community evenness with increasing hemeroby. The intermediate disturbance hypothesis was fully supported with respect to species richness. For the number of species, there is indeed a certain level of heterogeneity at which the number of species is highest. For another aspect of diversity, evenness, this pattern is not true. The evenness increases with increasing habitat disturbance. This result is due to a decrease in the abundance of dominant species.

Keywords: diversity; urbanization; bioindication; canonical correspondance analysis; variation fractioning.

\section{Introduction}

Hemeroby is an integrated indicator for measuring human impacts on environmental systems (Jalas, 1955; Sukopp, 1969; Kowarik, 2020). The intensity or frequency of the man-made disturbance determines its impact on the community (Battisti et al., 2016). Hemeroby was initially formulated in the context of the rural-urban gradient from natural to fully anthropogenic habitats (Walz \& Stein, 2014). Hemeroby has a complex nature and a variety of mechanisms to affect ecosystems. Urbanization is a form of environmental disturbance (Rebele, 1994; Putchkov et al., 2019). Along the rural-urban gradient the number and the density of human inhabitants increases (Montalvo et al., 2019). The urbanization rate is associated with an increase in road density (Shi et al., 2019), area with artificial cover and paved surfaces (Murata \& Kawai, 2018; Chen et al., 2020), and air and soil pollution (Duh et al., 2008; Jia et al., 2018). Urban forests are constantly exposed to elevated temperatures, carbon dioxide, nitrogen deposition and ozone (Carreiro \& Tripler, 2005). Urban soils, especially in urban parks and green areas may have a direct influence on human health (Simon et al., 2012). Nitrogen (N) deposition (Bettez \& Groffman, 2013; Martinez et al., 2014; Decina et al., 2018, 2020; Trammell et al., 2019), heavy metal content of soil (Simon et al., 2013) and plants (Simon et al., 2011), and litter decomposition rate (Nemergut et al., 2014; Brygadyrenko, 2015; Dorendorf et al., 2015; Melliger et al., 2017) vary significantly along the urban-rural gradient (McDonnell et al., 1997; McDonnell \&
Pickett, 1990). The urban flora and vegetation respond sensitively to manmade disturbance (Kowarik, 1990; Hill et al., 2002). Hemeroby is often used to assess disturbances in different vegetation types (Steinhardt et al., 1999; Fernández et al., 2002; Hill et al., 2003; Acosta et al., 2003; Fanelli et al., 2006; Testi et al., 2009; Schleupner \& Schneider, 2013; Battisti \& Fanelli, 2016). However, this concept has seldom been evaluated for animals (Dennis et al., 2004; Schleupner \& Link, 2008; Battisti \& Fanelli, 2016). It should be noted that the role of animals in assessing anthropogenic impacts on ecological systems is well documented. Animal species specifically respond to environmental disturbance due to their natural history and ecology (Sousa, 1984). Species-specific ecological traits can be considered as the strong predictors of sensitivity to disturbance (Mouillot et al., 2013). Naturalness reflects the distance from the primary natural condition (Angermeier, 2000), while hemeroby measures the degree of disturbance. The concept of naturalness or purity of the ecosystem was considered as the reference standard for assessing the impact of human activities on the landscape. For landscape assessment, hemeroby is used as the inverse of naturalness in its content (Angermeier, 2000; Geri et al., 2010; Winter, 2012; Walz \& Stein, 2014; Tian et al., 2020). Hemeroby can be considered as a combination of effects of disturbances on components of ecological systems (Steinhardt et al., 1999). Hemeroby can be clearly identified by estimating the species composition of any habitat type (Fanelli et al., 2006). Compared to generalists, specialized species may demonstrate a different reaction to disturbance (Wiens, 1989; Julliard 
et al., 2006; Devictor et al., 2008; Reif et al., 2013; Katayama et al., 2014; Büchi \& Vuilleumier, 2014).

The Urban Ecosystem Convergence Hypothesis (UECH) suggests that urbanization over time drives the structure and function of native ecosystems to the uniform state regardless of the prevailing climate and other local environmental factors and regimes (Pouyat \& Carreiro, 2003; Pouyat et al., 2017). This hypothesis assumes that the soil characteristics and the features of soil biota will be more similar in disturbed and managed soils than in the original natural soils which these urban soils replaced. This similarity of urban soil properties is explained by the convergence of soilforming factors in the urban environment (Hall et al., 2016; Epp Schmidt et al., 2017). Urban Ecosystem Convergence Hypothesis was tested in several studies (Epp Schmidt et al., 2017; Groffman et al., 2017; Pouyat et al., 2017). Homogenization of urban communities has been studied for microbes (Epp Schmidt et al., 2017, 2019), plants (Schwartz et al., 2006; Smart et al., 2006), plants and birds (Aronson et al., 2014), birds (van Rensburg et al., 2009), land birds, freshwater fish, terrestrial mammals, plants, and freshwater reptiles and amphibians (Olden et al., 2006), insect orders (Lizée et al., 2011; Knop, 2016).

The invertebrate communities in urban soils can be taxonomically and functionally diverse and contain detritivores, microbivores, predators and ecosystem engineers (Byrne et al., 2008; Byrne \& Bruns, 2004; Sophie Joimel et al., 2017; Rochefort et al., 2006; Schrader \& Böning, 2006). Urban soil invertebrate communities are affected by the physical and chemical characteristics of urban soils and by land use and management practices (Bray \& Wickings, 2019). Soil invertebrates are sensitive to many human activities and the resulting soil conditions, such as physical disturbance of soil cover, heavy metal pollution, pesticide contamination of soil, time of human exposure and land use history (Mcintyre et al., 2000; Pavao-Zuckerman \& Coleman, 2007; Pavao-Zuckerman, 2008; Jones \& Leather, 2012). Habitat loss occurs as the intensity of urbanization increases. At the same time, islands in an urban environment that retain the capacity for biota are becoming increasingly fragmented and smaller in the gradient of urban disturbance (Collins et al., 2000). Ecological corridors are landscape elements that avoid the negative impact of fragmentation on arthropod communities (Vergnes et al., 2012). Numerous anthropogenic activities suppress the abundance and diversity of soil invertebrate communities. The direction and scale of responses may vary from taxonomic group to group. Thus, in most invertebrates, the density in response to heavy metal contamination of soil decreases (Nahmani \& Lavelle, 2002; Santorufo et al., 2012; Pey et al., 2014; Pouyat et al., 2015). However, isopods show a positive density response to metal contamination in urban soils (Pouyat et al., 2015). Pesticides are also well-known to decrease invertebrate densities in urban soils. However, the effects can vary considerably with pesticide active ingredient, application rate, and frequency of use (Peck, 2009; Gan \& Wickings, 2017). Other human activities can have an evenly positive impact on soil invertebrate communities. It is known that growth of invertebrate density from different taxonomic and functional groups can be induced by increase of organic matter content in urban soils (Smith et al., 2006; Smetak et al., 2007; Byrne et al., 2008; Joimel et al., 2016; Joimel et al., 2017). Soil invertebrates are sensitive to the disturbance of soils, so they are valuable indicators of soil regimes (Nahmani \& Lavelle, 2002) and bioindicators of urban soil quality (Santorufo et al., 2012). In the short term, the diversity and abundance of soil invertebrate communities is declining due to urbanization. In the long term, an increase in the number of tolerant species may lead to changes in community structure and size (Salminen et al., 2001).

Among the methods currently being applied to quantify land use, the concept of hemeroby is the most challenging in terms of practicability of the method and quality of the resulting data (Fehrenbach et al., 2015). The classification into hemeroby classes perfectly captures the complexity of land use (Fehrenbach et al., 2015).

The aim of our study is to investigate the role of the hemeroby gradient in structuring the soil macrofauna community. We consider the phytoindication estimates of this gradient as a marker of hemeroby. We assume that the hemeroby affects both soil animals directly and the properties of their environment, which also affects them. Evaluating the values of various aspects of the influence of hemeroby on soil animals will provide the basis for identifying the focus of bioindication of hemeroby with soil animals.

\section{Methods}

Research area. The experimental polygon was located in the Botanical Garden of the Oles Honchar Dnipro National University (Dnipro City, Ukraine). There were 20 sites within the polygon (Fig. 1). On each of them at 105 points samples of soil macrofauna were taken, soil penetration resistance, electrical conductivity of soil, height of litter, height of grasses were measured. Within each site, a description of the vegetation cover was made.

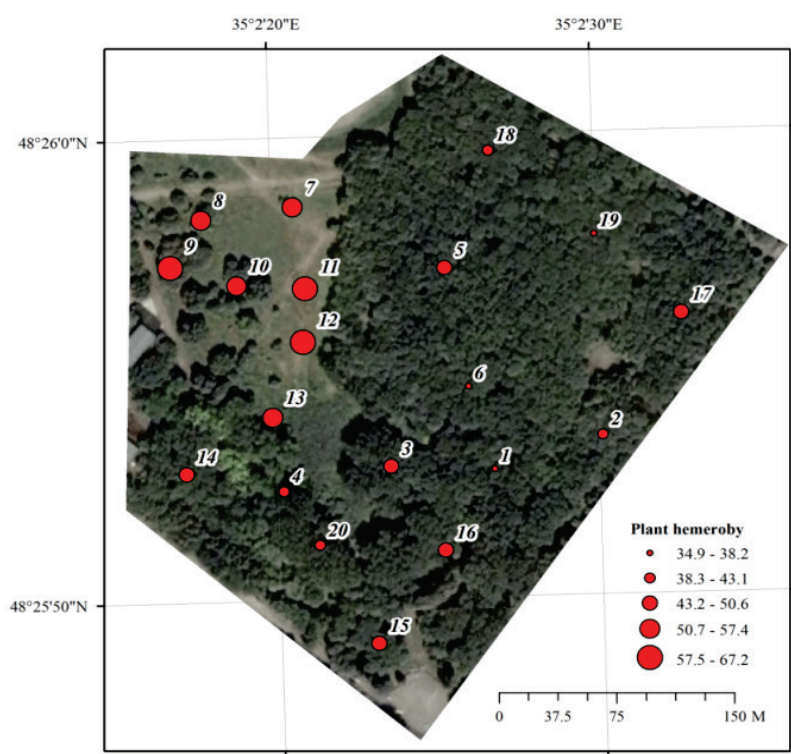

Fig. 1. Phytoindicator assessment of hemeroby for the investigated polygons: 1-20 are investigated polygons

Soil properties measurement. The measurement of the soil penetration resistance was made in the field using a hand penetrometer Eijkelkamp, to a depth of $100 \mathrm{~cm}$ with an interval of $5 \mathrm{~cm}$ (at the depths of $0-5$, $5-10, \ldots, 45-50 \mathrm{~cm}$ in a single repetition). To measure the electrical conductivity of the soil in situ, the sensor HI 76305 was used (Hanna Instruments, Woonsocket, R. I.). This sensor works in conjunction with the portable device $\mathrm{HI} 993310$ (at the depths of $0-5 \mathrm{~cm}$ in a three-times repetition).

Data collection. At each site we established a plot of $30 \times 14 \mathrm{~m}$, with 105 subplots of $2 \times 2 \mathrm{~m}$ organized in a regular grid. The site consisted of 7 transects. Each transect was made up of 15 subplots. The distance between rows in the subplot was $2 \mathrm{~m}$. The adjacent subplots were in close proximity. The macrofauna were manually collected from the soil samples from each subplot. Samples consisted of single blocks of soil, $25 \times$ $25 \times 30 \mathrm{~cm}^{3}$ deep, dug out quickly. A quadrat was fixed in the center of the subplot on the soil surface prior to soil sampling. The soil macrofauna were sorted and the animals were stored in $4 \%$ formaldehyde (Mathieu et al., 2004; Zhukov et al., 2018a, 2018b). Soil macrofauna was defined as an invertebrate group found within terrestrial soil samples which has more than $90 \%$ of its specimens in such samples visible to the naked eye (macroscopic organisms) (Warren \& Zou, 2002; Lavelle et al., 2003; Gholami et al., 2016). Geobionts (large soil invertebrates that permanently inhabit the soil) and geophiles (organisms that live in the soil only for particular phases of their lives) (Krivolutsky, 1992; Gholami et al., 2016; Butenko et al., 2017) were assessed.

The lists of vascular plant species were compiled for each site. The evaluation of the species projective cover was performed visually. The projective cover of plant species was recorded at ground level, the understorey (up to $2 \mathrm{~m}$ height) and canopy (above $2 \mathrm{~m}$ height). We were able to make species level identification for all sites.

Based on the description of the vegetation, an indication of the level of ecosystem hemeroby within the polygons was conducted. The Goncharenko (2017) scale, which is an adaptation of the Borhidi naturalness scale (Borhidi, 1995) to the realities of Ukrainian flora, was used as a scale of hemeroby. Hemeroby assessment was performed as a weighted average of the hemeroby value of plant species in the community:

$$
H V=\sum_{i=1}^{N} p_{i} * \boldsymbol{h} v_{i}
$$


where $H V$ is the estimation of the plant community hemeroby (values are in the range 0-100); $p_{i}$ is the projective cover of the $i$-th species; $h v_{i}$ is the indicator value of hemeroby for $i$-th species.

Phytoindication scales for Didukh (2011) include edaphic and climatic scales. The edaphic phytoindication scales include the soil water regime $(\mathrm{Hd})$, the variability of damping $(\mathrm{fH})$, the soil aeration $(\mathrm{Ae})$, the soil acidity $(\mathrm{Rc})$, the total salt regime $(\mathrm{Sl})$, the carbonate content in soil $(\mathrm{Ca})$ and nitrogen content in soil $(\mathrm{Nt})$. The climatic scales include the parameters of the thermal climate (thermoregime, Tm), humidity (Om), cryo-climate $(\mathrm{Cr})$ and the continentality of climate $(\mathrm{Kn})$. In addition to these, the lighting scale (Lc) is highlighted, which is characterized as a microclimate scale. Thermal properties of soils are indicated by a scale of the thermal regime, and hydrothermal is the scale of ombro mode. Phytoindicational estimation of environmental factors was performed by the ideal indicator method of Buzuk (2017).

Soil macrofauna identification. Adult and larvae specimens were counted and identified to species level. Earthworms were identified using Perel (1979), and Kunah et al. (2010), Lithobiomorpha with Zalesskaya (1978), Geophilomorpha with Bonato et al. (2014), Diplopoda with Cherny \& Golovach (1993), imago ground beetles with Kryzhanovsky (1964), larvae ground beetles with Gilyarov (1964), Dolin (1978), Andreeva (1990), Kabakov (2006), and Krivosheina (2012), woodlice with Schmolzer (1965), molluscs with Gural-Sverlova \& Gural (2012).

Ordination approaches and methods for niche parameters estimation. Weighted averaging can be used to estimate the species optimal value along the ecological gradient in cases of the symmetric bell-shaped response curves (ter Braak \& Looman, 1986). The method of the weighted averaging is reasonably good when the whole range of a species distribution is covered by samples. The species abundances were used as the weights in calculating the ecological factor average:

$$
W A=\frac{\sum_{i=\mathbf{1}}^{n} \text { Env }_{i} \times \text { Abund }_{i}}{\sum_{i=\mathbf{1}}^{n} \text { Abund }_{i}},
$$

where $E n v_{i}$ is the value of environmental variable in the $i$-th sample, and Abund $_{i}$ is the abundance of the species in the $i$-th sample.

The species tolerance which is presented by the width of the bell-shaped curve can be calculated as the square root of the weighted mean of the squared differences between the species optimum and the actual value in the sample. The value is analogous to standard deviation:

$$
S D=\sqrt{\frac{\sum_{i=\mathbf{1}}^{n}\left(E^{2} v_{i}-W A\right)^{2} \times \text { Abund }_{i}}{\sum_{i=\mathbf{1}}^{n} \text { Abund }_{i}}}
$$

If the complete range of a species distribution is covered and species response is symmetrically bell-shaped, then the estimation by means of weighted average is correct. In contrast, the estimate is biased if only a part of the range is covered. In this case, the estimate is shifted with respect to real value in the direction of the tail that is not truncated. The number of the species with truncated distribution will increase if the covered portion of the gradient is short and as a consequence the optimum estimates will be biased. The longer the environmental gradient, the more species will have their optima estimated correctly.

The use of symmetric Gaussian response functions in gradient analysis is not a universal approach due to systematic deviation of the real data from symmetric response (Austin, 1987; Austin, 1999). Huisman et al. (1993) hierarchical models (HOF) along with a symmetric response also include a skewed response. Apart from the five HOF-model, two bimodal (skewed and symmetric) response shapes were included to cope with species that are restricted to gradient extremes due to competition (Jansen \& Oksanen, 2013; Michaelis \& Diekmann, 2017). The Huisman-OlffFresco models expanded by Jansen-Oksanen (HOFJO) are ranked according to the increasing complexity of biological information contained (Huisman et al., 1993; Jansen \& Oksanen, 2013). Model I: no significant trend in space or time:

$$
y=M \frac{1}{1+e^{a}} .
$$

Model II: an increasing or decreasing trend where the maximum is equal to the upper bound $\mathrm{M}$ :

$$
y=M \frac{1}{1+e^{a+b x}} .
$$

Model III: an increasing or decreasing trend where the maximum is below the upper bound $\mathrm{M}$ :

$$
y=M \frac{1}{1+e^{a+b x}} \frac{1}{1+e^{c}} .
$$

Model IV: increase and decrease by the same rate - symmetrical response curve:

$$
y=M \frac{1}{1+e^{a+b x}} \frac{1}{1+e^{c-b x}} .
$$

Model $\mathrm{V}$ : increase and decrease by different rates - skewed response curve:

$$
y=M \frac{1}{1+e^{a+b x}} \frac{1}{1+e^{c+d x}} .
$$

Model VI: bimodal symmetric responses:

$$
y=M \frac{1}{1+e^{a+b x}} \frac{1}{1+e^{c+b(x-d)}}+\frac{1}{1+e^{a+b(x-d)}} \frac{1}{1+e^{c-b(x-d)}} .
$$

Model VII: bimodal skewed responses:

$$
y=M \frac{1}{1+e^{a+b x}} \frac{1}{1+e^{c+b(x-d)}}+L \frac{1}{1+e^{a+b(x-d)}} \frac{1}{1+e^{c-b(x-d)}} .
$$

where $y$ and $x$ are the response and the explanatory variable respectively, $a, b, c$ and $d$ the parameters to be estimated ( $b$ and $d$ have opposite signs), and $M$ - a constant which equals the maximal value which can be attained (for relative frequencies $M=1$, for percentages $M=100$ ), $L-$ a constant which equals the maximal value for minor extreme value.

Huisman-Olff-Fresco models were fitted in the R statistical program (v. 3.3.1) (R Developmental Core Team, 2019) using the package eHOF (Jansen \& Oksanen, 2013, version 3.2.2). To improve modeling results even for small data sets, the stability of model choice was double-checked by bootstrapping (100 samplings, default package setting) to ensure model robustness. The Akaike information criterion corrected for small data sets (AICc) was used (Burnham \& Anderson, 2002). In cases when the two procedures differed in their choice for the best model type, the bootstrapping model was preferred (Michaelis \& Diekmann, 2017). Optimum value and relative species tolerance limits, or the Central Borders, were calculated as implemented in the eHOF package (Jansen \& Oksanen, 2013). These are specified fractions of the curve maxima $\left(\max * \mathrm{e}^{-0.5}\right)$ and are calculated separately for the left (LowCB) and right (UppCB) hand side of the optimum (Heegaard, 2002).

To analyze the spatiotemporal variation in the species composition of invertebrate assemblages, multivariate ordination techniques were applied. Prior to analyses, species data were Hellinger-transformed (Legendre \& Gallagher, 2001). We subjected the Hellinger-transformed abundance matrix of species to correspondence analysis (CA), constrained correspondence analysis (CCA), and constrained redundancy analysis (RDA) to extract the major patterns of variation (Legendre \& Birks, 2012; ter Braak $\&$ Šmilauer, 2015). The environmental factors were fitted onto a CA-ordination by enfit function from the vegan library (Oksanen et al., 2018).

The constrained ordination approaches (correspondence or redundancy analysis) allowed assessment of the effects of the soil moisture as an explanatory variable on the invertebrate community with temporal, spatial, environmental factors and technosol type as condition variables. The detrended correspondence analysis (DCA) was used to discriminate whether species responses are primarily monotonic or primarily unimodal. To do this, the length of the first major gradient of variation in community data was estimated (ter Braak \& Prentice, 1988). If gradient length is more than two standard deviation, then constrained correspondence analysis (CCA) must be selected as ordination approach.

Otherwise constrained redundancy analysis (RDA) is most suitable. Species scores generated by the CA or CCA indicate the centre of the species' distribution in a unimodal model. Therefore, species scores represent the niche position (optimum) of species along the extracted axes. The standard deviations of species scores quantify the niche width. If the ordination axes are correlated with environmental gradients, the scores and the associated standard deviations can be used to characterize the niche properties of each species with respect to that gradient (Entling et al., 2007).

The strength of the association between species and clusters of the sampling points was determined by means of the indicator value index (IndVal) (Dufrêne \& Legendre, 1997) calculated by the function multipatt from the package indicspecies (Cáceres \& Legendre, 2009). For the statistical analyses we used the appropriate procedures of Statistica (Version 5.5, StatSoft Inc., www.statsoft.com) or R (version 3.5.2; R Core Team, 2018). 


\section{Results}

In total, 48,457 invertebrate (Annelida, Arthropoda and Mollusca) individuals of 6 classes, 13 orders, 50 families and 83 species or parataxonomic units were recorded (Table 1). The annelids comprise $78.8 \%$ of the total community and are represented by 11 species, of which Aporrectodea caliginosa dominates. Arthropods constitute $12.0 \%$ of the community and are represented by 61 species. Among the arthropods, Geophilus proximus, Schizoturanius dmitrievi, and Trachelipus rathkii are the dominant species. Molluscs account for $13.2 \%$ of the total community size and are represented by 11 species. The most abundant species of mollusc is Discus ruderatus.

Table 1

Taxonomic diversity and abundance of the soil macrofauna

\begin{tabular}{|c|c|c|c|c|c|}
\hline \multicolumn{3}{|l|}{ Results } & Taxons & Phase & $\begin{array}{l}\text { Individual } \\
\text { number }\end{array}$ \\
\hline \multirow{2}{*}{\multicolumn{3}{|c|}{ In total, 48,457 invertebrate (Annelida, Arthropoda and Mollusca) in- }} & Platyderus rufus (Duftschmid, 1812) & imago & 1 \\
\hline & & & Zabrus (Pelor) spinipes (Fabricius, 1798) & imago & 12 \\
\hline \multicolumn{3}{|c|}{ dividuals of 6 classes, 13 orders, 50 families and 83 species or parataxono- } & Zabrus (Zabrus) tenebrioides (Goeze, 1777) & imago & 7 \\
\hline \multirow{2}{*}{\multicolumn{3}{|c|}{$\begin{array}{l}\text { mic units were recorded (Table } 1 \text { ). The annelids comprise } 78.8 \% \text { of the } \\
\text { total community and are represented by } 11 \text { species, of which Aporrectodea }\end{array}$}} & Bembidion (Metallina) properans (Stephens, 1828) & imago & 21 \\
\hline & & & Carabus (Cancellocarabus) cancellatus Illiger, 1798 & imago & 1 \\
\hline \multicolumn{3}{|c|}{ caliginosa dominates. Arthropods constitute $12.0 \%$ of the community and } & Anisodactylus (Anisodactylus) nemorivagus (Duftschmid, 1812) & imago & 7 \\
\hline \multirow{2}{*}{\multicolumn{3}{|c|}{ are represented by 61 species. Among the arthropods, Geophilus prox- }} & Carabidae sp. & larvae & 72 \\
\hline & & & Harpalus flavescens (Piller \& Mitterpacher, 1783) & imago & 4 \\
\hline imus, Schizoturanius dmitrievr, and Irachelipu & $l$ are the & dominant & Ophonus (Metophonus) brevicollis (Audinet-Serville, 1821) & imago & 15 \\
\hline species. Molluscs account for $13.2 \%$ of the tot & & & Ophonus punctatulus (Duftschmid, 1812) & imago & 8 \\
\hline represented by 11 species. The most abundant & of moll & isc is Dis- & Pterostichus (Pseudomaseus) anthracinus (Illiger, 1798) & imago & 1 \\
\hline cus ruderatus. & & & $\begin{array}{l}\text { Stomis (Stomis) pumicatus (Panzer, 1796) } \\
\text { Family Cerambicidae }\end{array}$ & imago & 3 \\
\hline Table 1 & & & Carinatodorcadion carinatum (Pallas, 1771) & larvae & 111 \\
\hline Taxonomic diversity and abundance of the soil & tuna & & Family Cetoniidae & & \\
\hline & & & Cetonia aurata (Linnaeus, 1761) & larvae & 17 \\
\hline & & Individual & Family Chrysomelidae & & \\
\hline laxons & Phase & number & Chrysomelidae sp. & larvae & 4 \\
\hline Phylum Annelida & & & Family Curculionidae & & \\
\hline Class Oligohaeta & & & Bothynoderes affinis (Schrank, 1781) & larvae & 39 \\
\hline Ordo Haplotaxida & & & Family Dermestidae & & \\
\hline Family Lumbricidae & & & Dermestes (Dermestinus) laniarius Illiger, 1801 & larvae & 4 \\
\hline Aporrectodea caliginosa trapezoides (Duges, 1828) & adultus & 18096 & Family Elateridae & & \\
\hline Aporrectodea rosea rosea (Savigny, 1826) & adultus & 5124 & Agriotes sputator (Linnaeus, 1758) & larvae & 14 \\
\hline Dendrobaena octaedra (Savigny, 1826) & adultus & 982 & Athous (Athous) haemorrhoidalis (Fabricius, 1801) & larvae & 149 \\
\hline Dendrobaena veneta (Rosa, 1896) & adultus & 269 & Melanotus (Melanotus) brunnipes (Germar, 1824) & larvae & 74 \\
\hline Eisenia fetida (Savigny, 1826) & adultus & 33 & Family Staphylinidae & & \\
\hline Lumbricus rubellus Hoffmeister, 1843 & adultus & 6930 & Drusilla canaliculata (Fabricius, 1787) & imago & 1 \\
\hline Lumbricus terrestris Linnaeus, 1758 & adultus & 113 & Anotylus insecatus (Gravenhorst, 1806) & imago & 1 \\
\hline Octodrilus transpadanus (Rosa, 1884) & adultus & 1077 & Oxyporus (Oxyporus) rufus (Linnaeus, 1758) & imago & 2 \\
\hline Octolasion lacteum (Oerley, 1885) & adultus & 2349 & Philonthus (Philonthus) intermedius (Lacordaire, 1835) & imago & 1 \\
\hline Dendrodrilus rubidus (Savigny, 1826) & adultus & 82 & Rugilus (Rugilus) rufipes Germar, 1836 & imago & 1 \\
\hline Ordo Tubificida & & & Staphylinus caesareus Cederhjelm, 1798 & imago & 216 \\
\hline Family Enchytraeidae & & & Family Tenebrionidae & & \\
\hline Enchytraeus sp. & adultus & 1209 & Cylindronotus (Nalassus) brevicollis Kuster, 1850 & larvae & 3 \\
\hline Phylum Arthropoda & & & Family Melolonthidae & & \\
\hline Class Malacostraca & & & Amphimallon solstitiale (Linnaeus, 1758) & larvae & 268 \\
\hline Ordo Isopoda & & & Melolontha melolontha (Linnaeus, 1758) & larvae & 186 \\
\hline Family Oniscoidae & & & Rhizotrogus aestivus (Olivier, 1789) & larvae & 50 \\
\hline Armadillidium vulgare (Latreille, 1804) & adultus & 3 & Amphimallon assimile (Herbst, 1790) & larvae & 220 \\
\hline Family Trachelipodidae & & & Ordo Diptera & & \\
\hline Trachelipus rathkii (Brandt, 1833) & adultus & 888 & Family Therevidae & & \\
\hline Class Chilopoda & & & Thereva nobilitata (Fabricius, 1775) & larvae & 13 \\
\hline Ordo Geophilomorpha & & & Family Stratiomyidae & & \\
\hline Family Geophilidae & & & Stratiomys longicornis (Scopoli, 1763) & larvae & 310 \\
\hline Geophilus proximus C. L. Koch, 1847 & adultus & 1213 & Ordo Lepidoptera & & \\
\hline Pachymerium ferrugineum (C. L. Koch, 1835) & adultus & 17 & Family Noctuidae & & \\
\hline Ordo Lithobiomorpha & & & Agrotis clavis (Hufnagel, 1766) & larvae & 303 \\
\hline Family Lithobiidae & & & Class Arachnida & & \\
\hline Lithobius (Lithobius) forficatus (Linnaeus, 1758) & adultus & 2 & Ordo Opiliones & & \\
\hline Lithobius (Monotarsobius) curtipes C. L. Koch, 1847 & adultus & 32 & Family Phalangiidae & & \\
\hline Ordo Scolopendromorpha & & & Zacheus lupatus (Eichwald, 1830) & adultus & 19 \\
\hline Family Cryptopidae & & & Ordo Araneae & & \\
\hline Cryptops anomalans Newport, 1844 & adultus & 3 & Family Lycosidae & & \\
\hline Class Diplopoda & & & Pardosa lugubris (Walckenaer, 1802) & adultus & 277 \\
\hline Ordo Julida & & & Phylum Mollusca & & \\
\hline Family Julidae & & & Class Gastropoda & & \\
\hline Megaphyllum rossicum (Timotheew, 1897) & adultus & 145 & Ordo Pulmonata & & \\
\hline Ordo Polydesmida & & & Family Cochlicopidae & & \\
\hline Family Polydesmidae & & & Cochlicopa lubrica (O. F. Muller, 1774) & adultus & 1213 \\
\hline Schizoturanius dmitrievi (Timotheew, 1899) & adultus & 599 & Family Enidae & & \\
\hline Class Insecta & & & Brephulopsis cylindrica (Menke, 1828) & adultus & 331 \\
\hline Ordo Coleoptera & & & Chondrula tridens (O. F. Muller, 1774) & adultus & 815 \\
\hline Family Carabidae & & & Family Gastrodontidae & & \\
\hline Amara (Amara) aenea (De Geer, 1774) & imago & 120 & Zonitoides (Zonitoides) nitidus (O.F. Muller, 1774) & adultus & 53 \\
\hline Amara (Curtonotus) aulica (Panzer, 1796) & imago & 47 & Family Helicidae & & \\
\hline Amara similata (Gyllenhal, 1810) & imago & 9 & Helix (Helix) albescens Rossmassler, 1839 & adultus & 1 \\
\hline Amara sp. & larvae & 4 & Family Hygromiidae & & \\
\hline Badister (Badister) bullatus (Schrank, 1798) & imago & 58 & Euomphalia strigella (Draparnaud, 1801) & adultus & 7 \\
\hline Badister (Badister) lacertosus Sturm, 1815 & imago & 15 & Family Limacidae & & \\
\hline Brachinus (Brachinus) crepitans (Linnaeus, 1758) & imago & 24 & Limacus maculatus (Kaleniczenko, 1851) & adultus & 76 \\
\hline Calathus (Calathus) fuscipes (Goeze, 1777) & imago & 13 & Family Succineidae & & \\
\hline Calathus melanocephalus (Linne 1758) & imago & 5 & Succinella oblonga (Draparnaud, 1801) & adultus & 180 \\
\hline Calosoma (Calosoma) inquisitor (Linnaeus, 1758) & imago & 2 & Family Valloniidae & & \\
\hline Harpalus (Harpalus) affinis (Schrank, 1781) & imago & 52 & Vallonia pulchella (O. F. Muller, 1774) & adultus & 276 \\
\hline Harpalus (Pseudoophonus) griseus Panzer, 1796 & imago & 33 & Family Vitrinidae & & \\
\hline Harpalus (Pseudoophonus) rufipes (De Geer, 1774) & imago & 64 & Vitrina pellucida (O.F. Muller, 1774) & adultus & 208 \\
\hline Harpalus serripes (Quensel in Schonherr, 1806) & imago & 3 & Family Patulidae & & \\
\hline Harpalus tardus (Panzer, 1797) & imago & 2 & Discus (Discus) ruderatus (W. Hartmann, 1821) & adultus & 3224 \\
\hline Ophonus (Hesperophonus) azureus (Fabricius, 1775) & imago & 21 & & & \\
\hline
\end{tabular}

Zabrus (Pelor) spinipes (Fabricius, 1798)

Zabrus (Zabrus) tenebrioides (Goeze, 1777)

Bembidion (Metallina) properans (Stephens, 1828)

Carabus (Cancellocarabus) cancellatus Illiger, 1798

Anisodactylus (Anisodactylus) nemorivagus (Duftschmid, 1812) Carabidae sp.

Harpalus flavescens (Piller \& Mitterpacher, 1783)

Ophonus (Metophonus) brevicollis (Audinet-Serville, 1821)

Ophonus punctatulus (Duftschmid, 1812)

Pterostichus (Pseudomaseus) anthracinus (Illiger, 1798)

Stomis (Stomis) pumicatus (Panzer, 1796) Family Cerambicidae

Carinatodorcadion carinatum (Pallas, 1771) Family Cetoniidae

Cetonia aurata (Linnaeus, 1761 ) y Chrysomelidae Family Curculionidae

Class Oligohaet

Ordo Haplotaxida adulth

dultus

dultus

adultus us $\mathrm{sp}$

Family Trachelipodidae

Koch, 1847

(C. L. Koch, 1835)

Ordo Scolopendromorph

Class Diplopoda

Ordo Polydesmic

Class Insecta

Ordo Coleoptera

amily Carabidae

Amara similata (Gyllenhal, 1810)

is (Calathus) fuscipes (Goeze, 1777)

Calosoma (Calosoma) inquisitor (Linnaeus, 1758)

Harpalus (Harpalus) affinis (Schrank, 1781)

Harpalus (Pseudoophonus) rufipes (De Geer, 1774)

Harpalus tardus (Panzer, 1797)

(Hesperophonus) azureus (Fabricius, 1775)
Brachinus (Brachinus) crepitans (Linnaeus, 1758) 
Phytoindication reveals that the level of hemeroby within the studied polygons varies 34.9-67.2 (Fig. 1). There is a clear pattern that open spaces are the most exposed to anthropogenic transformation. Among forest communities, the most exposed to anthropogenic transformation are marginal communities in the zone of contact with urban environment objects surrounding the park. HOFJO-approach provides opportunities for species response modeling using more alternative models (Fig. 2). The model V and VI were the most optimal model of the species response to hemeroby gradient. Somewhat less often, the optimal models were IV, VII, and II (Fig. 3).

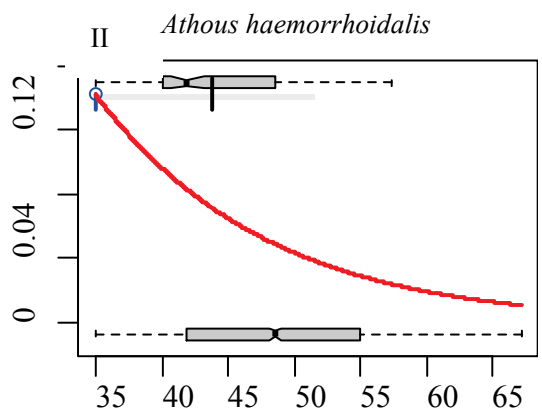

III Vitrinia pellusida
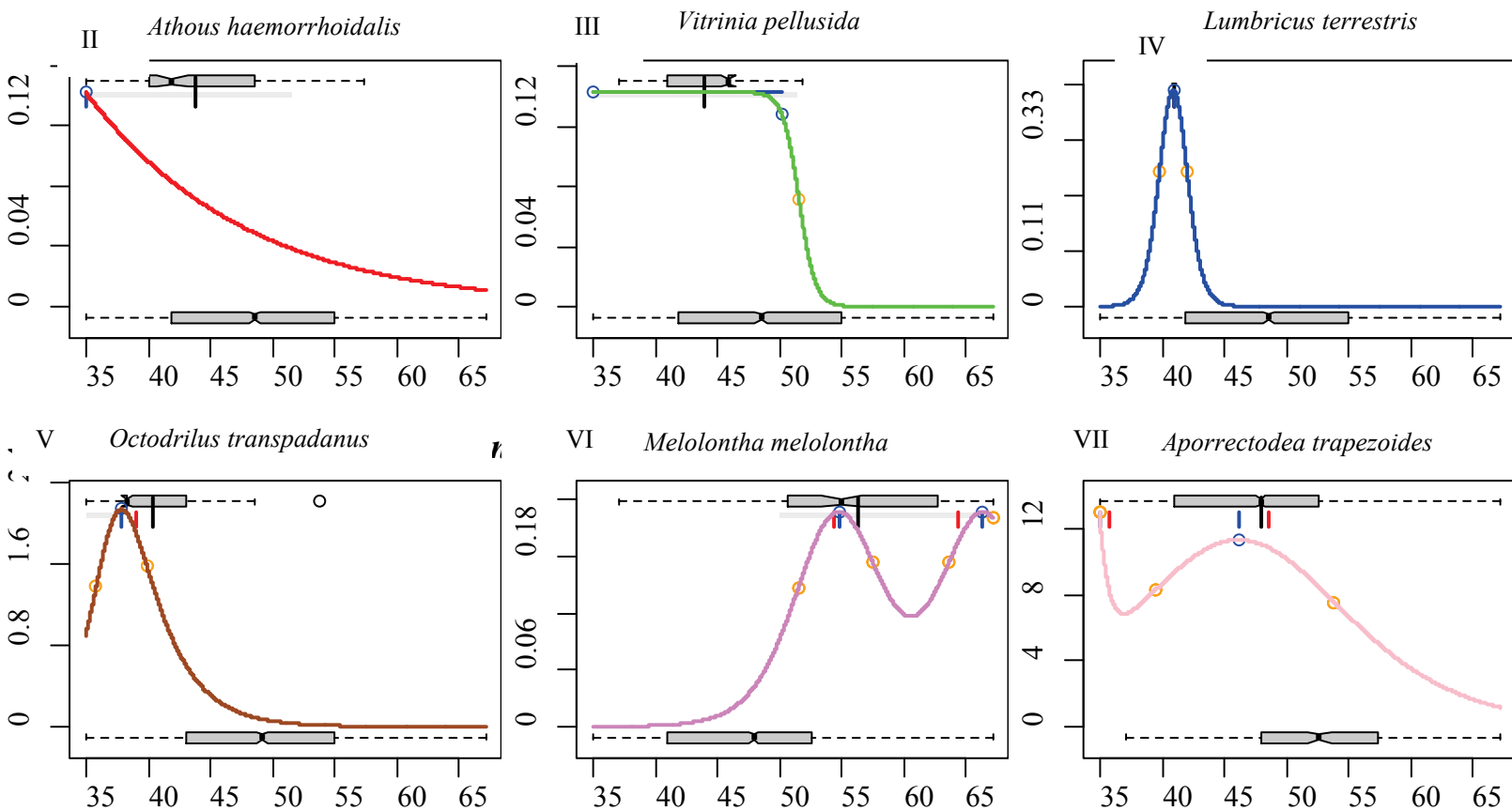

VII Aporrectodea trapezoides

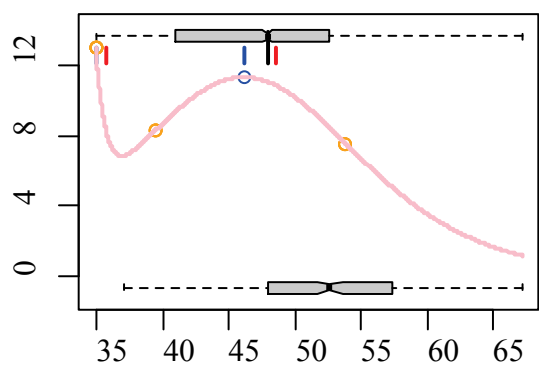

Fig. 2. HOFJO-models of species response to hemeroby gradient: $\mathrm{X}$-axis - the phytoindication assessment of the hemeroby;

Y-axis - the number of individuals; HOFJO-models: II - an increasing or decreasing trend where the maximum is equal to the upper bound;

$\mathrm{III}$ - an increasing or decreasing trend where the maximum is below the upper; IV - increase and decrease by the same rate - symmetrical response curve;

$\mathrm{V}$-increase and decrease by different rates - skewed response curve; VI - bimodal symmetric responses; VII - bimodal skewed responses

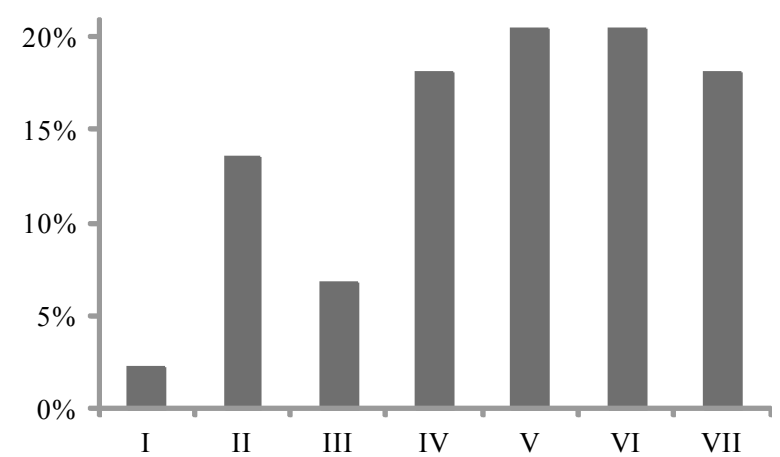

Fig. 3. The optimal models distribution of species response to the hemeroby gradient: $\mathrm{X}$-axis $-\mathrm{HOF}$ and two additional models of the species responses to the soil moisture gradient, Y-axis - the \% from the total number of species for which model is the best according to AICc;

HOFJO-models: I - no significant trend in space or time; II - an increasing or decreasing trend where the maximum is equal to the upper bound; III - an increasing or decreasing trend where the maximum is below the upper; IV - increase and decrease by the same rate-symmetrical response curve; $\mathrm{V}$ - increase and decrease by different rates - skewed response curve; VI - bimodal symmetric responses; VII - bimodal skewed responses

The weighted average factor value is a good approximation of the optimal factor level for the species in a symmetrical bell-shaped response model (Table 2). According to this indicator, the optimal factor level of the hemeroby for the soil macrofauna species ranges 34.9-66.0. Species also differ in degree of specialization to the factor of hemeroby, which was characterized by values of standard deviation of the average weighted estimation of hemeroby. The most stenotopic species are those whose optimum is in the middle part of the hemeroby range. Species with minimum and maximum hemeroby are characterized by high eurytopicity. The va- riety of HOFJO-models indicates that not all species have a weighted average as the best estimation of the optimum zone, despite the simplicity of their calculation. By taking into account the features of response models, we can make more accurate estimates of the quantitative characteristics of the influence of hemeroby on soil animal species.

Table 2

The position of the soil macrofauna species in the gradient of hemeroby regimes

\begin{tabular}{|c|c|c|c|c|c|c|c|}
\hline \multirow[t]{2}{*}{ Species } & \multicolumn{2}{|c|}{$\begin{array}{c}\text { Position within } \\
\text { hemeroby } \\
\text { gradient } \\
\end{array}$} & \multirow{2}{*}{$\begin{array}{l}\text { Mo- } \\
\text { del* }\end{array}$} & \multirow[t]{2}{*}{ Opt $_{\text {min }}$} & \multirow{2}{*}{ Opt $_{\max }$} & \multicolumn{2}{|c|}{$\begin{array}{l}\text { Hand side } \\
\text { of the optimum }\end{array}$} \\
\hline & $\begin{array}{l}\text { weighted } \\
\text { mean }\end{array}$ & $\mathrm{SD}$ & & & & $\begin{array}{c}\text { outer } \\
\text { border }_{\text {how }}\end{array}$ & $\begin{array}{c}\text { outer } \\
\text { border high }\end{array}$ \\
\hline Amara aenea & 55.59 & 7.11 & IV & 55.50 & - & 54.41 & 56.60 \\
\hline A. aulica & 52.33 & 4.79 & VI & 51.91 & 64.72 & 50.02 & 66.60 \\
\hline Amphimallon assimilis & 39.87 & 8.66 & $\mathrm{~V}$ & 38.37 & - & 34.90 & 39.50 \\
\hline A. solstitiale & 57.30 & 8.82 & IV & 57.18 & - & 56.58 & 57.79 \\
\hline Aporrectodea rosea & 47.39 & 3.10 & VII & 37.68 & 48.65 & 37.68 & 48.65 \\
\hline A.trapezoides & 46.14 & 5.53 & VII & 34.90 & 46.15 & 34.90 & 46.15 \\
\hline Aranea sp. & 50.65 & 7.22 & II & 67.20 & - & 34.90 & 67.20 \\
\hline $\begin{array}{l}\text { Athous } \\
\text { haemorrhoidalis }\end{array}$ & 43.64 & 6.65 & II & 34.90 & - & 34.90 & 51.51 \\
\hline Badister bullatus & 39.96 & 8.60 & II & 34.90 & - & 34.90 & 46.06 \\
\hline Bembidion sp. & 66.04 & 17.56 & II & 67.20 & - & 62.14 & 67.20 \\
\hline $\begin{array}{l}\text { Brephulopsis } \\
\text { cylindrica }\end{array}$ & 54.18 & 5.98 & VII & 53.03 & 63.31 & 53.03 & 63.31 \\
\hline Carabidae sp. (larv.) & 56.75 & 8.91 & IV & 61.54 & - & 51.96 & 67.20 \\
\hline Chondrula tridens & 49.67 & 5.96 & VI & 47.92 & 67.20 & 42.60 & 67.20 \\
\hline Cochlicopa lubrica & 43.06 & 6.42 & $\mathrm{~V}$ & 39.48 & - & 34.90 & 39.48 \\
\hline $\begin{array}{l}\text { Curculionidae sp. } \\
\text { (larv.) }\end{array}$ & 54.87 & 6.53 & VI & 52.95 & 67.20 & 50.29 & 67.20 \\
\hline Dendrobaena octaedra & 46.13 & 2.54 & VII & 34.90 & 46.25 & 34.90 & 46.25 \\
\hline D. veneta & 42.78 & 6.63 & VI & 42.26 & 67.20 & 42.26 & 67.20 \\
\hline Dendrodrilus rubidus & 41.12 & 7.36 & IV & 40.95 & - & 40.25 & 41.66 \\
\hline Discus ruderatus & 42.80 & 5.99 & $\mathrm{~V}$ & 41.29 & - & 34.90 & 41.29 \\
\hline Dorcadion caritum & 56.78 & 8.30 & V & 55.28 & - & 34.90 & 59.42 \\
\hline
\end{tabular}




\begin{tabular}{|c|c|c|c|c|c|c|c|}
\hline \multirow[t]{2}{*}{ Species } & \multicolumn{2}{|c|}{$\begin{array}{l}\text { Position within } \\
\text { hemeroby } \\
\text { gradient } \\
\end{array}$} & \multirow[t]{2}{*}{$\begin{array}{l}\text { Mo- } \\
\text { del* }\end{array}$} & \multirow[t]{2}{*}{$\mathrm{Opt}_{\text {min }}$} & \multirow[t]{2}{*}{$\mathrm{Opt}_{\max }$} & \multicolumn{2}{|c|}{$\begin{array}{c}\text { Hand side } \\
\text { of the optimum }\end{array}$} \\
\hline & $\begin{array}{c}\text { weighted } \\
\text { mean }\end{array}$ & $\mathrm{SD}$ & & & & $\begin{array}{c}\text { outer } \\
\text { border }_{\text {bw }}\end{array}$ & $\begin{array}{c}\text { outer } \\
\text { border high }\end{array}$ \\
\hline Enchytraeidae sp. & 46.36 & 2.58 & V & 46.37 & - & 34.90 & 46.37 \\
\hline Geophilus proximus & 47.76 & 6.78 & VI & 43.93 & 67.20 & 43.93 & 67.20 \\
\hline Harpalus affinis & 59.92 & 11.44 & VI & 59.47 & 67.20 & 57.24 & 67.20 \\
\hline H. griseus & 42.87 & 5.91 & III & 34.90 & 48.59 & 34.90 & 50.65 \\
\hline H.rufipes & 48.64 & 4.62 & I & - & - & 34.90 & 67.20 \\
\hline Noctuidae sp. (larv.) & 47.94 & 7.44 & VII & 43.66 & 66.22 & 34.90 & 67.20 \\
\hline Limacus maculatus & 51.81 & 11.22 & VII & 41.73 & 67.20 & 41.73 & 67.20 \\
\hline Lithobius curtipes & 34.90 & 13.58 & II & 34.90 & - & 34.90 & 35.52 \\
\hline Lumbricus rubellus & 46.63 & 4.89 & VII & 34.90 & 47.15 & 34.90 & 47.15 \\
\hline L. terrestris & 41.00 & 7.48 & IV & 40.87 & - & 40.87 & 40.87 \\
\hline $\begin{array}{l}\text { Megaphyllum } \\
\text { rossicum }\end{array}$ & 57.12 & 9.27 & IV & 61.79 & - & 50.85 & 67.20 \\
\hline Melanotus brunnipes & 41.80 & 6.80 & VII & 34.90 & 40.92 & 34.90 & 47.79 \\
\hline Melolontha melolontha & 56.07 & 8.20 & VI & 54.77 & 66.38 & 49.98 & 67.20 \\
\hline $\begin{array}{l}\text { Octodrilus } \\
\text { transpadanus }\end{array}$ & 39.68 & 8.84 & $\mathrm{~V}$ & 37.81 & - & 34.90 & 37.81 \\
\hline Octolasion lacteum & 48.53 & 6.56 & III & 34.90 & 67.20 & 67.20 & 67.20 \\
\hline Rhizotrogus aestivus & 57.89 & 9.41 & VI & 57.24 & 67.20 & 55.88 & 67.20 \\
\hline $\begin{array}{l}\text { Schizothuranius } \\
\text { dmitriewi }\end{array}$ & 48.67 & 5.84 & V & 40.86 & - & 34.90 & 65.52 \\
\hline Staphilinus caesareus & 47.63 & 5.54 & IV & 47.80 & - & 34.90 & 63.89 \\
\hline Stratiomyidae sp. & 44.64 & 5.82 & $\mathrm{~V}$ & 40.74 & - & 34.90 & 40.74 \\
\hline Succinea oblonga & 41.33 & 7.37 & IV & 40.29 & - & 37.12 & 43.45 \\
\hline Trachelipus rathkii & 48.61 & 6.53 & VI & 45.45 & 67.20 & 45.45 & 67.20 \\
\hline Vallonia pulchella & 40.64 & 7.99 & $\mathrm{~V}$ & 39.28 & - & 34.90 & 39.88 \\
\hline Vitrinia pellusida & 44.14 & 5.19 & III & 34.90 & 50.14 & 34.90 & 51.46 \\
\hline Zonitoides nitidus & 63.12 & 14.97 & II & 67.20 & - & 61.26 & 67.20 \\
\hline
\end{tabular}

Note: model* - HOFJO-models: I - no significant trend in space or time; II - an increasing or decreasing trend where the maximum is equal to the upper bound; III - an increasing or decreasing trend where the maximum is below the upper; IV - increase and decrease by the same rate - symmetrical response curve; $\mathrm{V}$-increase and decrease by different rates - skewed response curve; VI - bimodal symmetric responses; VII - bimodal skewed responses; $\mathrm{Opt}_{\min }$ - optimum or minimum optimum in the case of the bimodal response; $\mathrm{Opt}_{\max }$ - maximum optimum in the case of the bimodal response; Outer border iow $_{-}$low border of the response curve; Outer border high $_{\text {h }}$ - higher border of the response curve.

For ordination procedure of the community with monotonic patterns, the more appropriate is RDA, and with unimodal patterns, the more appropriate procedure is CCA (ter Braak \& Prentice, 1988). DCA revealed that the length of the first axis gradient is more than two standard deviations (4.88 in our case), which points to the appropriateness of applying the correspondence analysis (CA) and the constrained correspondence analysis (CCA) as an ordination procedure. CA-ordination axes may be explained by the hemeroby, soil variables, phytoindication estimation of the edaphic factors, and the site effect (Table 3 ).

The first four CA-axes are able to explain $47.4 \%$ of the total community variation. The CA-axis 1 is the most correlated with hemeroby, soil penetration resistance on the all range of the depth studied, litter depth, soil temperature and plant height. The phytoindication estimation of the edaphic factors reveals that CA-axis 1 is most dependent on the humidity level, nitrogen content and aeration regime. The CA-axis 2 is the most correlated with soil penetration resistance at depth $10-15, \ldots 25-30 \mathrm{~cm}$, soil electrical conductivity, litter depth, and plant height. The phytoindication estimation of the edaphic factors reveals that CA-axis 2 is most dependent on the soil acidity level. The CA-axis 3 is the most correlated with soil penetration resistance at depth $5-10, \ldots 15-20 \mathrm{~cm}$, and other soil parameters. The phytoindication estimation of the edaphic factors reveals that CA-axis 3 is most dependent on the soil acidity level and carbonate content. The CA-axis 4 is the most correlated with hemeroby, soil penetration resistance at depth $15-20, \ldots 45-50 \mathrm{~cm}$, soil electrical conductivity, and litter depth. The phytoindication estimation of the edaphic factors reveals that CA-axis 4 is most dependent on the salt content and variation of the humidity regime.

The HOFJO-approach showed that species responses to hemeroby gradient are mainly bell-shaped (for which CCA is the best ordination procedure). But the responses of many species are monotonic (for which the RDA is the best ordination solution). The fractioning of the animal community variability in relation to hemeroby, soil, edaphic, and climate factors was performed both on the basis of the CCA and RDA (Fig. 3). The variation partitioning of the community based on CCA-approach points to the major role of the complex factors that are the result of the interaction of factors. The results based on RDA-approach also indicate the significant role of interaction between weather and time factors. These results point to the need for extraction of the role of soil moisture factor interactions with other factors to assess precisely the influence of soil moisture on the dynamics of invertebrate communities.

Table 3

Fitting environmental hemeroby, soil, edaphic, climate and site variables onto an CA-ordination

\begin{tabular}{|c|c|c|c|c|c|c|}
\hline \multirow{2}{*}{ Predictors } & \multicolumn{4}{|c|}{ Axes, $\%$ inertia explained } & \multirow{2}{*}{$R^{2}$} & \multirow{2}{*}{$\operatorname{Pr}(>r)$} \\
\hline & CA1, 18.5 & CA2, 11.6 & CA3, 9.3 & CA4, 7.0 & & \\
\hline Hemeroby & -0.68 & -0.26 & 0.22 & 0.65 & 0.50 & 0.001 \\
\hline \multicolumn{7}{|c|}{ Soil variables } \\
\hline $0-5 \mathrm{~cm}$ & -0.98 & 0.08 & 0.20 & -0.02 & 0.15 & 0.001 \\
\hline $5-10 \mathrm{~cm}$ & -0.91 & -0.06 & 0.39 & 0.11 & 0.19 & 0.001 \\
\hline $10-15 \mathrm{~cm}$ & -0.82 & -0.23 & 0.40 & 0.34 & 0.25 & 0.001 \\
\hline $15-20 \mathrm{~cm}$ & -0.80 & -0.27 & 0.31 & 0.44 & 0.33 & 0.001 \\
\hline $20-25 \mathrm{~cm}$ & -0.78 & -0.24 & 0.30 & 0.49 & 0.37 & 0.001 \\
\hline $25-30 \mathrm{~cm}$ & -0.80 & -0.20 & 0.24 & 0.51 & 0.38 & 0.001 \\
\hline $30-35 \mathrm{~cm}$ & -0.83 & -0.10 & 0.33 & 0.44 & 0.40 & 0.001 \\
\hline $35-40 \mathrm{~cm}$ & -0.85 & -0.04 & 0.19 & 0.49 & 0.40 & 0.001 \\
\hline $40-45 \mathrm{~cm}$ & -0.84 & -0.03 & 0.23 & 0.49 & 0.39 & 0.001 \\
\hline $45-50 \mathrm{~cm}$ & -0.86 & -0.01 & 0.21 & 0.47 & 0.40 & 0.001 \\
\hline $\mathrm{EC}$ & -0.26 & -0.76 & -0.45 & 0.38 & 0.12 & 0.001 \\
\hline Litter & 0.70 & -0.50 & 0.47 & 0.21 & 0.13 & 0.001 \\
\hline Plant & 0.81 & -0.27 & 0.52 & 0.01 & 0.06 & 0.001 \\
\hline Temp & -0.86 & -0.05 & -0.49 & 0.15 & 0.36 & 0.001 \\
\hline \multicolumn{7}{|c|}{ Phytoindication estimation of the edaphic factors } \\
\hline $\mathrm{Hd}$ & 0.84 & 0.12 & -0.30 & -0.43 & 0.55 & 0.001 \\
\hline $\mathrm{fH}$ & -0.66 & 0.16 & 0.00 & 0.73 & 0.38 & 0.001 \\
\hline $\mathrm{Rc}$ & -0.01 & 0.66 & 0.73 & 0.17 & 0.04 & 0.001 \\
\hline $\mathrm{Sl}$ & 0.13 & 0.01 & -0.11 & -0.99 & 0.26 & 0.001 \\
\hline $\mathrm{Ca}$ & -0.32 & 0.19 & 0.83 & 0.41 & 0.44 & 0.001 \\
\hline $\mathrm{Nt}$ & 0.73 & 0.04 & -0.25 & -0.63 & 0.42 & 0.001 \\
\hline Ae & 0.91 & -0.17 & 0.08 & -0.37 & 0.30 & 0.001 \\
\hline \multicolumn{7}{|c|}{ Phytoindication estimation of the climate factors } \\
\hline $\mathrm{Tm}$ & -0.46 & -0.18 & 0.46 & 0.74 & 0.11 & 0.001 \\
\hline Om & 0.25 & -0.40 & -0.38 & -0.79 & 0.18 & 0.001 \\
\hline $\mathrm{Kn}$ & -0.80 & -0.33 & 0.42 & 0.25 & 0.37 & 0.001 \\
\hline $\mathrm{Cr}$ & 0.78 & -0.15 & -0.49 & -0.35 & 0.37 & 0.001 \\
\hline $\mathrm{Lc}$ & -0.69 & -0.46 & -0.03 & 0.55 & 0.32 & 0.001 \\
\hline \multicolumn{7}{|c|}{ Site effect } \\
\hline Sites & - & - & - & - & 0.65 & 0.001 \\
\hline
\end{tabular}

Note: $\mathrm{Hd}$ - the soil water regime, $\mathrm{fH}$ - the variability of damping, $\mathrm{Ae}$ - the soil aeration, $\mathrm{Rc}$ - the soil acidity, $\mathrm{Sl}$ - the total salt regime, $\mathrm{Ca}$ - the carbonate content in soil, $\mathrm{Nt}$-nitrogen content in soil, $\mathrm{Tm}$-thermoregime, $\mathrm{Om}$ - humidity, $\mathrm{Cr}$-cryo-climate, $\mathrm{Kn}$-the continentality of climate, $\mathrm{Lc}$ - the lighting scale.

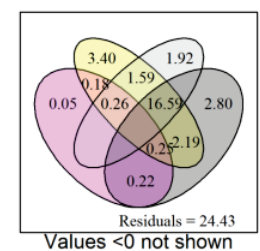

$a$

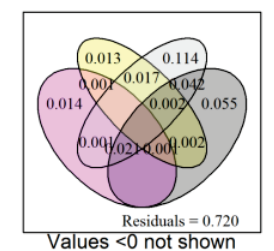

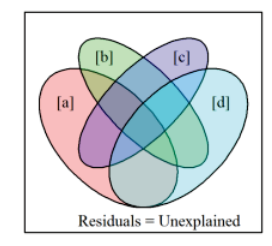

$c$
Fig. 3. Variance partitioning between hemeroby, soil, edaphic, and climate explanatory variables: $a$ - using chi square in constrained correspondence analysis (CCA), $b$ - using adjusted R-squared in redundancy analysis (RDA); $c$ - the interpretation of the symbols: $[a]$ - variation explained solely by the hemeroby variable; $[b]$ - variation captured by soil variables corresponds to pure soil effect; $[c]$ - variation captured by phytoindication estimation of the edaphic factors corresponds to pure edaphic effect; $[d]$ - variation explained by phytoindication estimation of the climate variables corresponds to pure climate effect; $[a]+[b]$ - variation explained both by hemeroby and soil variables; $[a]+[c]$ - variation explained both by hemeroby and the edaphic variables; $[b]+[c]$ - variation explained both by the soil and edaphic variables; $[c]+[d]$ - variation explained both by edaphic and climate variables; all the variance fractions shown are significant $(\mathrm{P}<0.001)$ 
The hemeroby influence can explain $2.5 \%$ of the community variation $(\mathrm{F}=54.04, \mathrm{P}<0.001$, Table 4$)$. The hemeroby influence with taking into account of the conditional effect of the soil can explain $2.4 \%$ of the community variation $(\mathrm{F}=54.61, \mathrm{P}<0.001)$. Additionally taking into account the effect on the community of the edaphic factors leads to decrease of the explained variation to the level $1.3 \%$ of the community variation $(\mathrm{F}=28.64, \mathrm{P}<0.001)$. The hemeroby influence with taking into account of the conditional effect of the soil, edaphic, and climate factors can explain $1.1 \%$ of the community variation $(\mathrm{F}=28.9, \mathrm{P}<0.001)$.

\section{Table 4}

Correlation between phytoindication estimation of the hemeroby and CCA axes derived from the canonical correspondence analysis of soil macrofauna community with hemeroby as predictor and soil, edaphic and climatic variables as covariates $(\mathrm{N}=2100)$

\begin{tabular}{|c|c|c|c|c|c|c|c|}
\hline \multirow{3}{*}{$\begin{array}{c}\text { CCA } \\
\text { axis }\end{array}$} & \multirow{3}{*}{$r(\mathrm{X}, \mathrm{Y})$} & \multirow{3}{*}{$R^{2}$} & \multirow{3}{*}{ t } & \multirow{3}{*}{$p$-level } & \multicolumn{3}{|c|}{ Regression models } \\
\hline & & & & & \multicolumn{2}{|c|}{$\begin{array}{l}\text { dependent: } \\
\text { planthemeroby }\end{array}$} & $\begin{array}{l}\text { dependent: } \\
\text { axis }\end{array}$ \\
\hline & & & & & constant & slope & constant slope \\
\hline emeroby & 0.74 & 0.54 & 50.06 & $<0.001$ & 48.50 & 4.92 & $-5.37 \quad 0.11$ \\
\hline & 0.72 & 0.52 & 47.98 & & 48.50 & 4.8 & -5.26 \\
\hline +Edaphic & 0.39 & 0.15 & 19.17 & $<0.001$ & 48.53 & 2.21 & -3.29 \\
\hline +Climate & 0.31 & 0.10 & 14.97 & $<0.001$ & 48.52 & 1.81 & -2.61 \\
\hline
\end{tabular}

CCA axis is actually a zoological scale of hemeroby (Fig. 4). It strongly correlates with the plant scale of hemeroby (Table 5). Accounting for soil, edaphic and climatic variables as covariate reduces this correlation, which indicates that the patterns of soil animal hemeroby are also due to the transformation effect of the corresponding environmental factors.

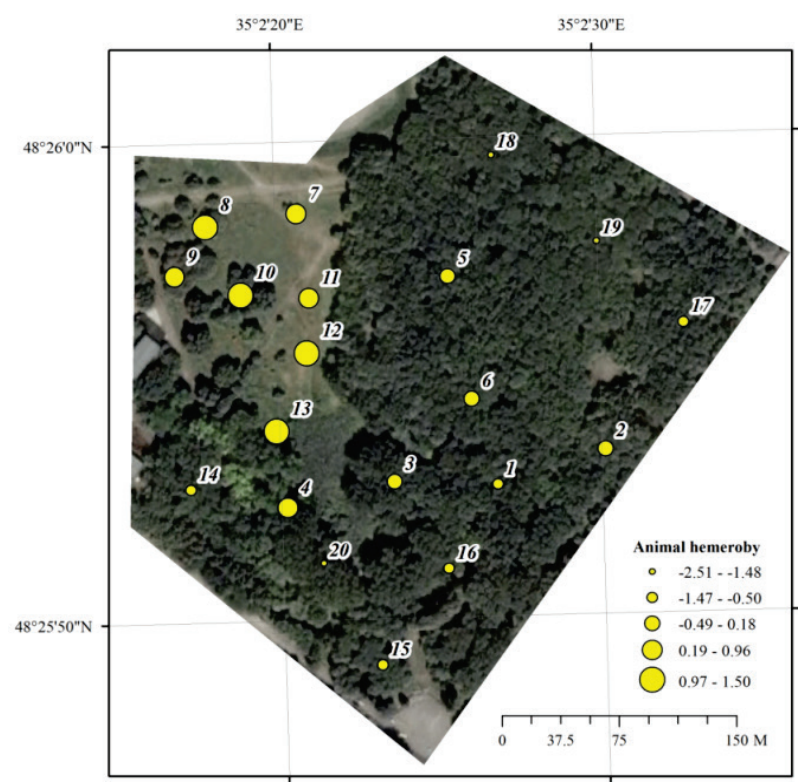

Fig. 4. Variation in soil macrofauna community hemeroby level: $1-20$ are investigated polygons

There was a regular change in the soil macrofauna community size and diversity in the hemeroby gradient (Fig. 5). The limiting influence of anthropogenic transformation of the environment on the abundance of soil macrofauna community is clearly marked at the level of hemeroby above average. Species diversity of the community is greatest at moderate hemeroby level. Both relatively little transformed habitats and strongly transformed ones are characterized by lower species richness of soil macrofauna community. The Shannon index shows a clear upward trend with increasing hemeroby. The Pielou index indicates that the main reason for this trend is an increase in community evenness with increasing hemeroby.

Species scores along the CCA-axis reveal position of the species optimum within hemeroby gradient. Adding variables as covariate allow one to test the effect of the corresponding variables on the generation of the hemeroby patterns. If the position of the species along the axis changes significantly when taking into account the influence of the variable as covariates, then the hemeroby pattern for this species is due to the action of this variable. Species can be classified by means of cluster analysis based on their optimal positions for different variants of the canonical correspondence analysis (Fig. 6).
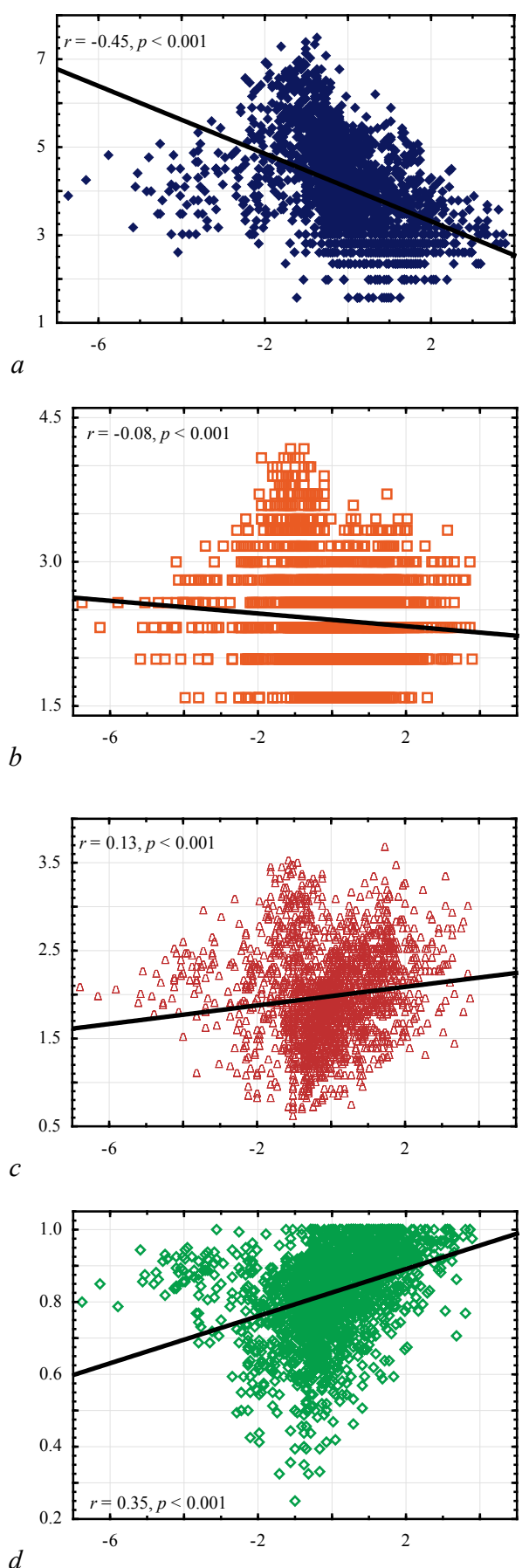

Fig. 5. Dependence of community abundance $(a)$, species diversity $(b)$, Shannon diversity $(c)$ and Pielou evenness $(d)$ on the soil macrofauna hemeroby: the $\mathrm{x}$-axis is the CCA-axis scores obtained as a result of ordination of soil macrofauna community by means of canonical correspondence analysis with phytoindication scale of hemeroby as a predictor; the y-axis: $a$-community abundance (individuals per sample, logarithm on the base 2); $b$ - species diversity (logarithm of species number on the base 2); $c$-Shannon diversity index; $d$-Pielou evenness; the line indicates the best approximation of the data cloud by the least squares method

We have identified six clusters that are sensitive to the influence of various factors in the formation of hemeroby patterns. Members of cluster 1 are characterized by the lowest hemeroby and are not sensitive to the role of environmental factors in the formation of hemeroby patterns. Members of clusters 2-5 are practically not sensitive to the influence of 
soil properties in the formation of hemeroby patterns. The members of cluster 6 , which are characterized by the highest hemeroby, are affected by all studied groups of environmental indicators, including soil properties.

\section{Table 5}

Variation explained by the hemeroby and hemeroby with soil properties, edaphic and climatic factors as covariates and species scores on the CCA-axis (optimum $\pm \mathrm{SE}$ )

\begin{tabular}{|c|c|c|c|c|}
\hline & $\begin{array}{l}\text { Hemeroby, } \\
R^{2}=0.025\end{array}$ & $\begin{array}{c}\text { Soil*, } \\
R^{2}=0.024\end{array}$ & $\begin{array}{l}\text { Edaphic**, } \\
R^{2}=0.013\end{array}$ & $\begin{array}{c}\text { Climate***, } \\
R^{2}=0.011\end{array}$ \\
\hline Amara aenea & $0.85 \pm 0.017$ & $0.77 \pm 0.018$ & $-0.74 \pm 0.042$ & $-0.22 \pm 0.025$ \\
\hline A. aulica & $0.52 \pm 0.017$ & $0.53 \pm 0.016$ & & -0.35 \\
\hline A. similata & $-0.73 \pm 0.009$ & $-0.66 \pm 0.007$ & $-0.17 \pm 0.038$ & $0.32 \pm 0.038$ \\
\hline Amara sp. (larv.) & $-0.98 \pm 0.014$ & $-0.78 \pm 0.012$ & $-0.61 \pm 0.032$ & $-1.67 \pm 0.041$ \\
\hline Amphimallon assimilis & & & & $-0.48 \pm 0.023$ \\
\hline A. solstitiale & $1.04 \pm 0.023$ & $1.10 \pm 0.025$ & $0.51 \pm 0.033$ & $0.04 \pm 0.016$ \\
\hline Anisodactylus nemorivagus & $0.09 \pm 0.004$ & $0.15 \pm 0.004$ & $0.61 \pm 0.015$ & $0.51 \pm 0.018$ \\
\hline Aporrectodea rosea & $-0.09 \pm 0.014$ & $-0.08 \pm 0.014$ & $0.04 \pm 0.025$ & $0.26 \pm 0.025$ \\
\hline A. trapezoides & $-0.10 \pm 0$ & $-0.09 \pm 0.019$ & $-0.07 \pm 0.027$ & $-0.06 \pm 0.02$ \\
\hline Aranea sp. & $0.47 \pm 0.030$ & $0.48 \pm 0.030$ & $0.23 \pm 0.033$ & $0.16 \pm 0.030$ \\
\hline Athous haemorrhoidalis & $-0.52 \pm 0.018$ & & 0.025 & $-0.22 \pm 0.02$ \\
\hline Badister bullatus & -0.95 & $-0.87 \pm$ & -0.1 & 0.04 \\
\hline B. lacertosus & & & & \pm 0.01 \\
\hline Bembidion sp. & 0.023 & $1.96 \pm 0.021$ & .038 & 0.031 \\
\hline Brachinus crepitans & 0.016 & $1.20 \pm 0.016$ & .017 & 0.010 \\
\hline Brephulops & & $0.60 \pm 0.015$ & & \\
\hline Calathus fusc & 0.018 & $0.20 \pm 0.015$ & $0.55 \pm 0.005$ & $0.58 \pm 0.01$ \\
\hline Carabidae sp & 1.09 & $1.09 \pm 0.020$ & & 0.37 \\
\hline Cetonia aur & & $0.77 \pm 0.027$ & & \\
\hline Chondrulat & 028 & $0.45 \pm$ & .034 & $0.25 \pm 0.036$ \\
\hline Cochlicopa lubrica & & & & \\
\hline Curculionid & & & & \\
\hline Dendrobaen & -0.2 & $-0.33=$ & & 0.98 \\
\hline & & & & \\
\hline rodrilus rubidus & & & & -0.8 \\
\hline Discus ruder & -0.5 & & & -0.2 \\
\hline Dorc & & & & \\
\hline Eisenia fetida & -0.6 & & & -0.09 \\
\hline Agriotes sputator & & & & \\
\hline Encl & -0.2 & $-0.25 \pm$ & & \\
\hline Geophilus proximus & & $0.16 \pm$ & & 0.19 \\
\hline Harpalus affinis & & $1.42 \pm 0.0$ & & 0.5 \\
\hline H.flavescens & & $0.67=$ & & -0.2 \\
\hline H.griseus & -0.8 & & & -0.4 \\
\hline H. rufipes & & & & 0.1 \\
\hline Noctuidae sp. (larv.) & & 0.20 & & $0.1^{1}$ \\
\hline Limacus maculatus & & $0.63 \pm$ & & 0.03 \\
\hline & & & & \\
\hline Lumbricus rubellus & & & & 0.0 \\
\hline L. terrestris & & & & -0.8 \\
\hline Megaphyllum rossicum & & $1.21=$ & .031 & 0.4 \\
\hline Melanotus brunni & & $-0.81 \pm$ & -1.0 & -0.6 \\
\hline Melolontham & & & & 0.2 \\
\hline Octodrilus transpadamus & -0.93 & $-1.05 \pm$ & & $-0.36 \pm 0.02$ \\
\hline Octolasion lacteum & & & & $0.06 \pm 0.03$ \\
\hline Ophonus c & & & & \\
\hline O. brevicollis & $0.94 \pm 0.026$ & $1.04 \pm 0.028$ & & -0.1 \\
\hline O.punctatulus & $-0.06 \pm 0.004$ & $0.02 \pm 0.004$ & & \pm 0.01 \\
\hline Pachimerium ferrugineum & & & & \\
\hline Rhizotrogus aestivus & $1.12 \pm 0.017$ & $1.16 \pm 0.022$ & $0.68 \pm 0.025$ & $0.11 \pm 0.01$ \\
\hline Schizothuran & $0.27 \pm 0.020$ & $0.20 \pm 0.021$ & $0.20 \pm 0.027$ & $0.00 \pm 0.03$ \\
\hline Staphilinus caesareus & & & & \\
\hline Staphilinus sp. & $-1.59 \pm 0.011$ & $-1.36 \pm 0.011$ & $-0.83 \pm 0.013$ & $-0.29 \pm 0.00$ \\
\hline & & $-0.32 \pm 0.016$ & & \\
\hline Succinea oblonga & $-0.92 \pm 0.017$ & $-0.80 \pm 0.015$ & $-0.77 \pm 0.037$ & $-1.28 \pm 0.05$ \\
\hline Therevidae sp. & $1.05 \pm 0.024$ & $1.16 \pm 0.025$ & & $0.07 \pm 0.01$ \\
\hline Trachelipus rathkii & $0.36 \pm 0.0$ & $0.35 \pm 0.0$ & $0.19 \pm 0$. & $0.16 \pm 0.03$ \\
\hline Vallonia pulchella & $-0.96 \pm 0.016$ & $-0.84 \pm 0.015$ & $-0.93 \pm 0.036$ & $-1.30 \pm 0.04$ \\
\hline Vitrinia pellusida & $-0.63 \pm 0.01$ & $-0.55 \pm 0.013$ & $-0.68 \pm 0.0$ & $-0.47 \pm 0.041$ \\
\hline Zabrus spinipes & & $1.04 \pm 0.012$ & $0.85 \pm 0.016$ & $0.31 \pm 0.01$ \\
\hline Z. tenebrioides & $0.49 \pm 0.005$ & $0.41 \pm 0.006$ & $-0.06 \pm 0.006$ & $-0.52 \pm 0.00$ \\
\hline Zonitoides nitidus & $1.75 \pm 0.023$ & $1.72 \pm 0.023$ & $1.15 \pm 0.039$ & $1.08 \pm 0.03$ \\
\hline Zacheus lupatus & $2.20 \pm 0.018$ & $1.49 \pm 0.038$ & $1.60 \pm 0.067$ & $1.22 \pm 0.05$ \\
\hline
\end{tabular}

Notes: * - hemeroby as predictor and soil as covariate, ** - hemeroby as predictor and soil and edaphic as covariates, $* * *$ - hemeroby as predictor and soil, edaphic, and climate as covariates.

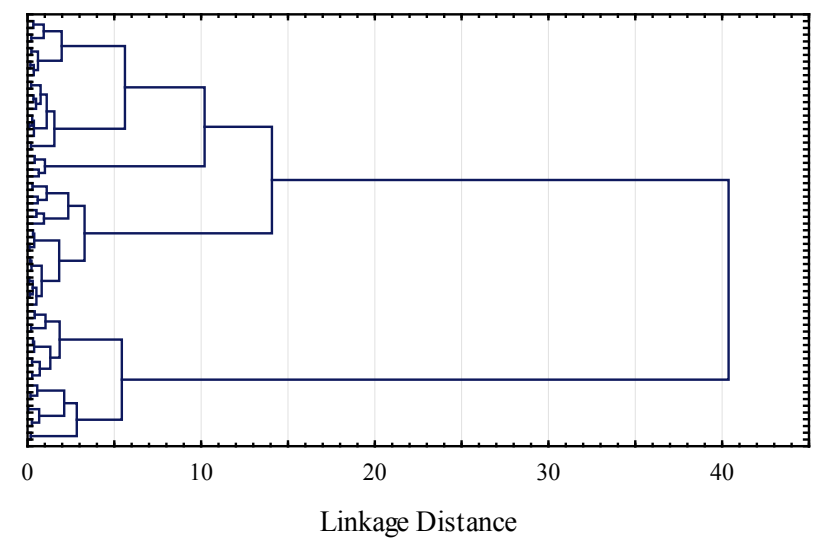

Fig. 6. Cluster analysis of species based on their optimal positions along the CCA axis with different combinations of environment factors as covariate

On the basis of the relation to the hemeroby factor, species in the clusters are classified into the following ecological groups: mega-hemerophobes, hemerophobes, sub-hemerophobes, hemi-hemerophiles, sub-hemerophiles, hemerophiles (Fig. 7).

Sites were classified into five clusters based on the scores of the CCA-axes, which corresponded to the levels of hemeroby estimated by vegetation cover (Fig. 7). Cluster 1 corresponds to the sites with the lowest anthropogenic transformation level, while cluster 5 corresponds to the sites with the highest anthropogenic transformation level. Clusters can be placed according to the levels of homogeneity: cluster $1-\mathrm{H} 2$ Ahemerobic, cluster $2-\mathrm{H} 3$ Mesohemerobic, cluster 3-H4 Mesohemerobic, cluster 4-H5 Mesohemerobic; cluster 5-H6 Alpha-euhemerobic.

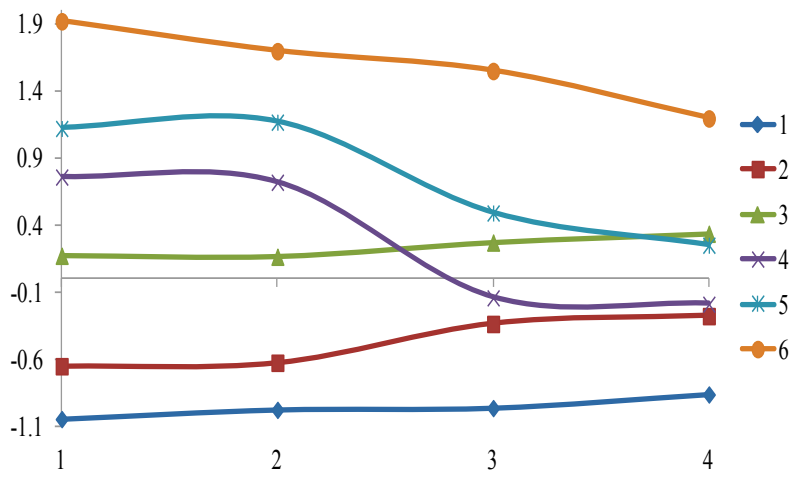

Fig. 7. Averaged positions for clusters of an optimum zone on CCA-axes with different combinations of environment factors as covariate: the abscissa axis: $1-\mathrm{CCA}$ results with hemeroby as a predictor; 2 -also with soil variables as covariates; 3 -also with edaphic predictors as covariates; 4 -also with climate predictors as covariates; ordinate axis is averaged value of optimums of species, which are included in the corresponding cluster; species clusters: 1 - mega-hemerophobes;

2-hemerophobes; 3 -sub-hemerophobes; 4 -hemi-hemerophiles; 5 -sub-hemerophiles; 6 -hemerophiles

Soil animal species can serve as indicators of hemoroby levels (Table 6). For level H2 ahemerobic there are 11 indicator species, for level $\mathrm{H} 3$ mesohemerobic there are 7 indicator species, for level $\mathrm{H} 4$ mesohemerobic there are 7 indicator species, for level $\mathrm{H} 5$ mesohemerobic there are 12 indicator species, for level H6 there are 17 indicator species. There is a correspondence between the levels of hemeroby of biotopes and types of species responses to hemeroby (Fig. 8). Biotopes with $\mathrm{H} 2$ and $\mathrm{H} 3$ hemeroby levels are represented by mega-hemerophobes and hemerophobes (Table 7). The difference between these levels is quantitative: megahemerophobes prevail in $\mathrm{H} 2$ ahemerobic conditions, while in $\mathrm{H} 3$ mesohemerobic conditions there is almost equal ratio between mega-hemerophobes and hemerophobes. Sub-hemerophobes predominate in H4 mesohemerobic condition. Hemi-hemerophiles predominate in $\mathrm{H} 5$ mesohemerobic condition. Sub-hemerophiles predominate in $\mathrm{H} 6$ alpha-euhemerobic and hemerophiles are represented only in these conditions. 


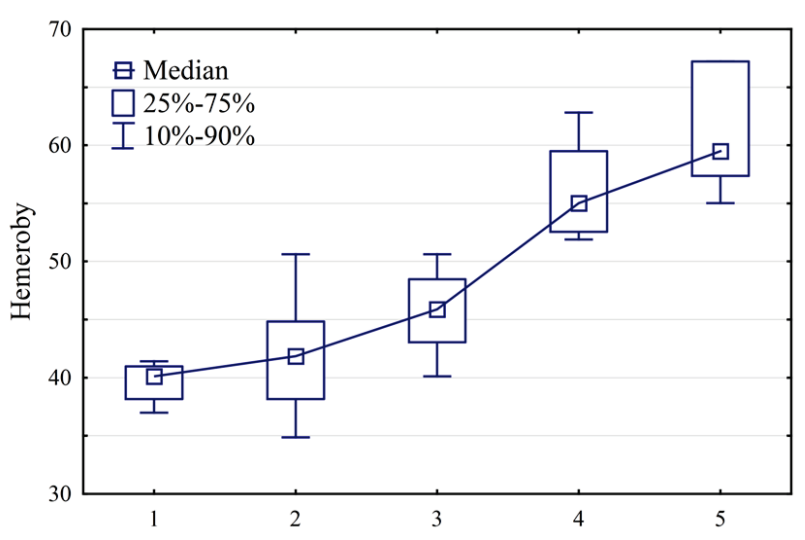

Fig. 8. Values of phytoindication estimates of hemeroby for clusters of soil macrofauna: the $\mathrm{x}$-axis is the cluster of soil macrofauna

(1-H2 ahemerobic, 2- $\mathrm{H} 3$ mesohemerobic, 3- $\mathrm{H} 4$ mesohemerobic, 4-H5 mesohemerobic; 5 - H6 alpha-euhemerobic), the $y$-axis is the phytoindication estimation of hemeroby

\section{Discussion}

The phytoindicator assessment of the degree of hemeroby indicates that within the studied park ecosystems the levels of anthropogenic transformation from low to above the average are represented. It can be assumed that the hemeroby is also reflected in the properties of the soil macrofauna community. The total abundance of the community, its diversity and structure may be aspects of the response to the hemeroby. Structural reconstructions of a community under the influence of an anthropogenic transformation may be due to different sensitivity of species to such effects. Soil macrofauna is a very numerous component of urbanized ecosystems. Our results show that the abundance of soil macrofauna is on average $369 \mathrm{ind} . / \mathrm{m}^{2}$. This level is higher than that of natural ecosystems which are close to the Dnipro city. Thus, in poplar-willow forest in the floodplain of the River Dnipro the abundance of soil macrofauna was $91.4 \pm 20.2 \mathrm{ind} . / \mathrm{m}^{2}$ (Zhukov et al., 2019), in deciduous woodland - 197.8 $\pm 27.9 \mathrm{ind} . \mathrm{m}^{2}$ (Zhukov et al., 2018), in deciduous forest $-321.5 \pm 43.2$ ind. $/ \mathrm{m}^{2}$ (Dubinina, 2018), in floodplain oak forest $-178.4 \pm 26.9 \mathrm{ind} . / \mathrm{m}^{2}$ (Zhukov et al., 2018). The decrease in the abundance of soil macrofauna is typical for high levels of ecosystem hemeroby, while ecosystems close to natural regimes are characterized by a wide range of community abundance variation. Thus, with high levels of hemeroby, the abundance of soil animals decreases, however, the opposite is not true: the fact of decrease in abundance can be due to both hemeroby and other reasons.

Detritivores have been used for landscape stress indications (Paoletti \& Bressan, 1996; Paoletti, 1999b, 1999a; Paoletti et al., 2007; Paoletti \& Hassall, 1999). Earthworms are a typical component of urban soil fauna and are generally considered as beneficial organisms to improve soil regimes for plant growing (Tóth et al., 2020). The earthworms constitute the basis of the park's soil macrofauna community. They predominate in the community in abundance and are represented by 10 species. It is important to note that among the earthworms the endogeic forms predominate and the abundance of epigeic forms is very small. Such feature is quite consistent, as the litter block of the ecosystem is most exposed to anthropogenic impact. The soil environment has protective properties and ensures the existence of a large and diverse community even at relatively high levels of anthropogenic impact. Anecic earthworms (Octodrilus transpadanus and, to a lesser extent, Lumbricus terrestris) have an important indicative value. These species are sensitive to the integrity of the entire soil cover from litter to deep layers. Therefore, anecic can be indicators of the remnants of the most preserved natural communities. Earthworms, particularly anecic, perform important ecological functions. Earthworms make a significant contribution to soil infiltration (Ehlers, 1975). The role of anecic species in enhancing soil infiltration is most important (Bouché \& Al-Addan, 1997). The soil infiltration rate was found to be correlated to earthworm biomass, burrow length, surface and volume, but not with burrow diameter, hydraulic tortuosity or with earthworm number and soil profile depth (Bouché \& Al-Addan, 1997; Capowiez et al., 2014;
Jouquet et al., 2008). The water stability of soil aggregates is significantly increased as a result of earthworms' activity (Griffiths et al., 2018). In turn, an increase in the level of hemeroby has a negative impact on the implementation of relevant ecosystem services performed with the participation of soil animals.

Table 6

Indicator values of species for hemeroby levels identification

\begin{tabular}{|c|c|c|c|c|c|c|c|}
\hline \multirow{2}{*}{ Species } & \multicolumn{5}{|c|}{ Hemeroby levels } & \multirow{2}{*}{ Stat } & \multirow{2}{*}{$p$-value } \\
\hline & $\mathrm{H} 2$ & $\mathrm{H} 3$ & $\mathrm{H} 4$ & $\mathrm{H} 5$ & H6 & & \\
\hline Amara aenea & 0 & 0 & 0 & 1 & 0 & 0.26 & 0.001 \\
\hline A. aulica & 0 & 0 & 0 & 1 & 0 & 0.20 & 0.001 \\
\hline A. similata & 0 & 0 & 1 & 0 & 0 & 0.07 & 0.325 \\
\hline Amara sp. & 1 & 0 & 0 & 0 & 0 & 0.16 & 0.001 \\
\hline Amphimallon assimilis & 0 & 1 & 0 & 0 & 0 & 0.32 & 0.001 \\
\hline A. solstitiale & 0 & 0 & 0 & 0 & 1 & 0.48 & 0.001 \\
\hline Anisodactylus nemorivagus & 0 & 0 & 1 & 0 & 0 & 0.08 & 0.103 \\
\hline Aporrectodea rosea & 0 & 0 & 1 & 0 & 0 & 0.61 & 0.001 \\
\hline A. trapezoides & 0 & 0 & 1 & 0 & 0 & 0.56 & 0.001 \\
\hline Aranea sp. & 0 & 0 & 0 & 0 & 1 & 0.28 & 0.001 \\
\hline Athous haemorrhoidalis & 0 & 1 & 0 & 0 & 0 & 0.24 & 0.001 \\
\hline Badister bullatus & 0 & 1 & 0 & 0 & 0 & 0.19 & 0.001 \\
\hline B. lacertosus & 0 & 0 & 0 & 0 & 1 & 0.19 & 0.001 \\
\hline Bembidion sp. & 0 & 0 & 0 & 0 & 1 & 0.32 & 0.001 \\
\hline Brachinus crepitans & 0 & 0 & 0 & 0 & 1 & 0.30 & 0.001 \\
\hline Brephulopsis cylindrica & 0 & 0 & 0 & 1 & 0 & 0.44 & 0.001 \\
\hline Calathus fuscipes & 0 & 0 & 1 & 0 & 0 & 0.08 & 0.138 \\
\hline Carabidae sp. & 0 & 0 & 0 & 0 & 1 & 0.18 & 0.001 \\
\hline Cetonia aurata & 0 & 0 & 0 & 0 & 1 & 0.08 & 0.202 \\
\hline Chondrula tridens & 0 & 0 & 0 & 0 & 1 & 0.35 & 0.001 \\
\hline Cochlicopa lubrica & 1 & 0 & 0 & 0 & 0 & 0.82 & 0.001 \\
\hline Curculionidae sp. & 0 & 0 & 0 & 1 & 0 & 0.14 & 0.012 \\
\hline Dendrobaena octaedra & 0 & 0 & 1 & 0 & 0 & 0.42 & 0.001 \\
\hline D. veneta & 0 & 1 & 0 & 0 & 0 & 0.27 & 0.001 \\
\hline Dendrodrilus rubidus & 1 & 0 & 0 & 0 & 0 & 0.37 & 0.001 \\
\hline Discus ruderatus & 1 & 0 & 0 & 0 & 0 & 0.56 & 0.001 \\
\hline Dorcadion carinatum & 0 & 0 & 0 & 1 & 0 & 0.27 & 0.001 \\
\hline Eisenia fetida & 1 & 0 & 0 & 0 & 0 & 0.16 & 0.001 \\
\hline Agriotes sputator & 0 & 0 & 0 & 1 & 0 & 0.13 & 0.005 \\
\hline Enchytraeidae sp. & 0 & 0 & 1 & 0 & 0 & 0.39 & 0.001 \\
\hline Geophilus proximus & 0 & 0 & 1 & 0 & 0 & 0.37 & 0.001 \\
\hline Harpalus affinis & 0 & 0 & 0 & 0 & 1 & 0.33 & 0.001 \\
\hline H.flavescens & 0 & 0 & 0 & 1 & 0 & 0.09 & 0.034 \\
\hline H.griseus & 1 & 0 & 0 & 0 & 0 & 0.10 & 0.107 \\
\hline H. rufipes & 0 & 0 & 1 & 0 & 0 & 0.13 & 0.062 \\
\hline Noctuidae sp. & 0 & 0 & 1 & 0 & 0 & 0.19 & 0.17 \\
\hline Limacus maculatus & 0 & 0 & 0 & 0 & 1 & 0.22 & 0.001 \\
\hline Lithobius curtipes & 0 & 1 & 0 & 0 & 0 & 0.14 & 0.003 \\
\hline Lumbricus rubellus & 0 & 0 & 1 & 0 & 0 & 0.53 & 0.001 \\
\hline L. terrestris & 1 & 0 & 0 & 0 & 0 & 0.14 & 0.01 \\
\hline Megaphyllum rossicum & 0 & 0 & 0 & 0 & 1 & 0.52 & 0.001 \\
\hline Melanotus brunnipes & 1 & 0 & 0 & 0 & 0 & 0.36 & 0.001 \\
\hline Melolontha melolontha & 0 & 0 & 0 & 0 & 1 & 0.32 & 0.001 \\
\hline Octodrilus transpadanus & 0 & 1 & 0 & 0 & 0 & 0.52 & 0.001 \\
\hline Octolasion lacteum & 0 & 0 & 0 & 1 & 0 & 0.39 & 0.001 \\
\hline Ophonus azureus & 0 & 0 & 0 & 1 & 0 & 0.13 & 0.019 \\
\hline O. brevicollis & 0 & 0 & 0 & 0 & 1 & 0.15 & 0.002 \\
\hline O. punctatulus & 0 & 0 & 1 & 0 & 0 & 0.10 & 0.024 \\
\hline Pachimerium ferrugineum & 0 & 0 & 0 & 0 & 1 & 0.14 & 0.002 \\
\hline Rhizotrogus aestivus & 0 & 0 & 0 & 0 & 1 & 0.35 & 0.001 \\
\hline Schizothuranius dmitriewi & 0 & 0 & 0 & 1 & 0 & 0.32 & 0.001 \\
\hline Staphilinus caesareus & 0 & 1 & 0 & 0 & 0 & 0.16 & 0.496 \\
\hline Staphilinus sp. & 0 & 1 & 0 & 0 & 0 & 0.12 & 0.007 \\
\hline Stratiomyidae sp. & 1 & 0 & 0 & 0 & 0 & 0.23 & 0.006 \\
\hline Succinea oblonga & 1 & 0 & 0 & 0 & 0 & 0.62 & 0.001 \\
\hline Therevidae sp. & 0 & 0 & 0 & 0 & 1 & 0.18 & 0.001 \\
\hline Trachelipus rathkii & 0 & 0 & 0 & 1 & 0 & 0.26 & 0.133 \\
\hline Vallonia pulchella & 1 & 0 & 0 & 0 & 0 & 0.71 & 0.001 \\
\hline Vitrinia pellusida & 1 & 0 & 0 & 0 & 0 & 0.41 & 0.001 \\
\hline Zabrus spinipes & 0 & 0 & 0 & 1 & 0 & 0.10 & 0.029 \\
\hline Z. tenebrioides & 0 & 0 & 0 & 1 & 0 & 0.11 & 0.012 \\
\hline Zonitoides nitidus & 0 & 0 & 0 & 0 & 1 & 0.43 & 0.001 \\
\hline Zacheus lupatus & 0 & 0 & 0 & 0 & 1 & 0.23 & 0.001 \\
\hline
\end{tabular}

Centipedes, millipedes and terrestrial isopods were used for evaluation of the habitat naturalness (Tuf \& Tufova, 2008). Standardised sampling of soil epigean arthropods were used in environmental assessment for conservation status of the protected areas (Borges et al., 2005). The prevalence of the soil layer over the litter layer is emphasized by the ratio of the endogeic Geophilomorpha to the epigeic Lithobiomorpha. The low abun- 
dance of the litter dwelling $M$. rossicum should also be noted. Thus, both in the structure of earthworm and centipede communities, we see the predominance of soil dwelling forms over litter dwelling forms, which is the direct consequence of anthropogenic ecosystem transformation. As in our study, the urbanization was shown to be followed by a reduction in the species and functional diversity of millipedes (Bogyó et al., 2015; Tóth \& Hornung, 2019).

\section{Table 7}

The correspondence between the levels of hemeroby and types of responses of species to the hemeroby (the number of species with the corresponding type of response that are indicators of the respective level of hemeroby)

\begin{tabular}{|c|c|c|c|c|c|c|c|}
\hline \multirow{2}{*}{ Hemeroby levels } & \multicolumn{6}{|c|}{ Types of responses of species to the hemeroby* } & \multirow{2}{*}{ Total } \\
\hline & 1 & 2 & 3 & 4 & 5 & 6 & \\
\hline H2 Ahemerobic & 6 & 5 & - & - & - & - & 11 \\
\hline H3 Mesohemerobic & 2 & 5 & - & - & - & - & 7 \\
\hline H4 Mesohemerobic & - & - & 7 & - & - & - & 7 \\
\hline H5 Mesohemerobic & - & - & 2 & 9 & 1 & - & 12 \\
\hline H6 Alpha-euhemerobic & - & - & 3 & - & 10 & 4 & 17 \\
\hline Total & 8 & 10 & 12 & 9 & 11 & 4 & 54 \\
\hline
\end{tabular}

Note: 1 - mega-hemerophobes; 2 - hemerophobes; 3 - sub-hemerophobes; 4 hemi-hemerophiles; 5 -sub-hemerophiles; 6 -hemerophiles.

Woodlice are herpetobiont saprophages, which are important decomposers of leaf litter and represented by two species, of which the most abundant is Trachelipus rathkii. The recolonization of woodlice into the urban habitats is considerably restricted due to their lower trophic level (Nagy et al., 2018). The woodlice are very sensitive to the decreasing quantity and changes in the quality of leaf litter resulting from various land use practices (Souty-Grosset et al., 2005). This and other features of the biology of terrestrial isopods make them appropriate organisms for assessing ecosystem sustainability (Paoletti \& Hassall, 1999).

The soil insect community is characterized by high diversity. The litter dwelling Carabidae family is diverse and consists of 28 species, of which $A$. aenea dominates. Carabid beetle response to urbanisation was demostrated to be useful to evaluate the importance of urban woodlands to serve as hot-spots for biodiversity conservation (Croci et al., 2008). The Staphylinidae family is represented by 6 species, of which the most numerous is $S$. caesareus. It should be noted that four Staphylinidae species (Staphylinus caesareus, Drusilla canaliculata, Philonthus intermedius, and Xantholinus longiventris) were identified as being eudominants of the urban ceonosis of Dnipro city. It was revealed that both carabid abundance and species richness demonstrate a tendency to increase from the city centers to the rural surroundings (Niemelä, 1999; Niemelä et al., 2002; Niemelä \& Kotze, 2009) and rove beetles species richness increased significantly with decreasing urbanization (Simon et al., 2013; Magura et al., 2013). It should be noted that hand sorting sampling is not the best method to take into account the species richness of herpetobiont animals. More complete species lists of the litter dwelling soil insects in the ecosystems of Dnipro city is presented in work where soil traps were used (Brygadyrenko, 2016; Putchkov et al., 2019; Komaromi et al., 2019). But the grounddwelling spider species richness was found to be significantly higher in the urban sites compared to the suburban and rural ones, which was due to the increase in the number of species in urban areas that preferred open habitat (Magura et al., 2010). The carabid and staphylinid communities revealed that removal of decaying wood as a result of the direct anthropogenic habitat transformation favours open-habitat specialists (Deichsel, 2006). The response of different functional groups of carabids to urban-rural gradients may help to develop simple tools and protocols for assessing ecological effects of human-caused landscape changes (Niemelä et al., 2000).

In spite of the higher species richness of the herpetobiont insect community, which is represented mainly by adults, soil dwellers at the larval stage are more numerous among the insects. There are numerous members of the Melolonthidae family, which is represented by only 4 species. Soil larvae C. carinatum, A. haemorrhoidalis, S. longicornis and A. clavis are abundant. It should be noted that while herpetobiont insects are represented mainly by predatory forms, soil insect larvae are mainly phytophagous. The trophic levels may be a crucial driver of the responses to urbanization. Urbanization was suggested to have a less harmful effect on predators (Nagy et al., 2018). Our results support this assumption.

The mollusc community is diverse and numerous. This group has a high bioindication ability (Kunakh \& Kovalenko, 2019; Kunakh et al., 2018; Yorkina et al., 2018, 2019). In the ecosystems studied 11 species of molluscs were found, among which the most numerous are $D$. ruderatus, C. lubrica and Ch. tridens.

One of the mechanisms for influencing urbanization is homogenization of the physical and natural environment environment, which favours the spreading of "urban-adaptable" species (McKinney, 2006) and these landscape patterns induced by urbanization are similar across the world (Niemelä \& Kotze, 2009). Soil animal species show regular patterns of response to the gradient of hemeroby regimes. Hemeroby is an important structural factor, so there are very few species that do not show a consistent pattern of response to anthropogenic ecosystem transformation. Species that occupy boundary positions in the gradient exhibit monotonic response curve types. The most typical are unimodal response (symmetrical and asymmetrical) and bimodal response (symmetrical and asymmetrical). Unimodal response curves indicate the presence of optimal hermometric conditions for some species, which are different from the minimum anthropogenic load. It can be assumed that the anthropogenic load at some level of exposure acts as a non-specific stress factor, which is similar to natural stressors. Natural stressors are one of the reasons for the diversity of communities, which is what we observe. We showed that community diversity is greatest at an average level of community transformation. The asymmetric shape of response curves can best be explained by the presence of biotic interactions. Hemeroby changes the competitive advantages of species, affecting the efficiency of their interactions. This explains the occurrence of more than one optimum zone.

Different hypotheses have been proposed to explain the response of species to urbanization. The increasing disturbance hypothesis claims that species richness monotonously decreases with the increasing levels of disturbance (Gray, 1989). We have established that this hypothesis is only valid for mega-hemerophobes and hemerophobes. These species monotonically decrease in number or disappear from the community under increasing conditions of hemerogeneity. For other species, this hypothesis is not relevant. Other species form the largest part of the soil macrofauna community, so this hypothesis does not explain the general pattern of diversity variability in the gradient of hemeroby.

The intermediate disturbance hypothesis predicts that species richness is the highest in the moderately disturbed suburban area (Connell, 1978). Our results fully support this hypothesis with respect to species richness. For the number of species, there is indeed a certain level of heterogeneity at which the number of species is highest. For another aspect of diversity, evenness, this pattern is not true. The evenness increases with increasing habitat disturbance. This result is due to a decrease in the abundance of dominant species.

The assessment of the pattern of species responses to environmental gradients is important for choosing an adequate community ordination procedure. The monotonic dependence indicates the adequacy of redundancy analysis (Muller, 1981; Pélissier et al., 2003; Kleyer et al., 2012). The nonlinear dependence of species response to environmental factors, which can be explained by a bell-shaped curve, indicates the adequacy of the application of canonical correspondence analysis (Palmer, 1993; Godefroid \& Koedam, 2007; Li et al., 2019). Nonmetric multidimensional scaling as a robust procedure should be considered as the optimal solution in such a situation (Minchin, 1987; Shaw et al., 2019). However, in order to solve the tasks we have set, it is important to have a partial ordination procedure (Borcard et al., 1992), which was solved for canonical correspondence analysis. Therefore, our application of different ordination techniques is done with the understanding that these approaches do not always fully correspond to the real nature of the mutual variability in species abundance in a community.

Correspondence analysis is an indirect ordination method (Palmer, 1993). The axes selected as a result of this procedure point to the high role of hemeroby in the structuring of the soil macrofauna community. Hemeroby manifests itself in changing a number of properties of ecological systems. Thus, the growth of the hemeroby is accompanied by an increase in soil penetration resistances, which is quite expected, as recreation is an 
important aspect of hemeroby in urban park conditions. The increase in hemeroby is followed by a decrease in litter thickness. This phenomenon is also associated with the reduction of the litter dwelling component of the soil macrofauna. Hemeroby increase is also indicated by the increase in aridity of conditions. It should also be noted that hemeroby is not the only factor that affects the variability of the soil macrofauna community. However, an increase in the intensity of the hemeroby factor is accompanied by a consistent variability of natural factors. For example, the hemeroby is associated with increased lighting in ecosystems, a decrease in humidity levels, the content of available forms of nitrogen in soil, aeration and an increase in the contrast of the humidification regime. Therefore, both specific reactions of soil macrofauna to anthropogenic impact and reactions to the variability of natural ecological regimes are observed among the reactions to hemeroby. Character of specificity is also not quite unambiguous. It is more correct to consider the formulation that it is either a specific reaction to the hemeroby, or that we are talking about the reaction of factors, not investigated in explicit form, that are correlated with hemeroby.

Urbanization radically changes the physical and chemical properties of the soil (Lo \& Marcotullio, 2000; Marcotullio et al., 2008), and has a significant impact on the biota that inhabits the soil (Turbé et al., 2010; Wall et al., 2015). Urbanization generates a local disturbance gradient, which in turn generates a biotic (McKinney, 2006) or ecological (Groffman et al., 2014) homogenization gradient. Hemeroby is an environmental factor of complex nature (Kowarik, 1990; Battisti et al., 2016). The response of soil animal species to hemeroby is hierarchical. The anthropogenic transformation of ecological systems, which leads to hemeroby, embraces vegetation, soil, climatic regimes and also directly affects soil animals. However, there is another point of view according to which the greater diversity of habitats in urban and industrial areas promotes the higher species diversity of urban ecosystems compared to neighboring natural ones (Rebele, 1994). Under the conditions of low disturbance, communities tend to be relatively stable. If a community is disturbed by low intensity or frequency, more competitive species dominate. Communities with high intensity or frequency disturbances are generally unstable and dominated by species that are less competitive but more adapted to a dynamic environment (Wilson, 1994; McCabe \& Gotelli, 2000; Roxburgh et al., 2004; Wood et al., 2017). The growth of the hemeroby of the soil macrofauna is accompanied by a consistent transformation of soil cover, vegetation and climatic regimes. This is, on the one hand, the reason for the specificity of the response to the hemeroby by soil animals, and on the other hand, the reason for the consistency of the response to anthropogenic transformation with other ecosystem components. Soil animals are the most sensitive to the transformation of the soil habitat. Animals most sensitive to hemeroby are immediately eliminated in the presence of any forms of negative impact and in this sense are not selectively sensitive to any anthropogenic impact. The soil performs a protective function for moderately sensitive forms and they primarily respond to significant changes in the edaphic and climatic regimes. Hemerobic-resistant forms are practically ideal quantitative indicators of hemeroby, because with increasing anthropogenic transformation they change their abundance almost linearly.

\section{Conclusion}

Hemeroby is a complex trend of transformation of various components of ecosystems due to anthropogenic influence. This is the cause of coordinated changes in soil, climate and communities of living organisms under disturbance. However, the components of ecosystems have their own specificity, so the clarification of this specificity makes it possible to more fully assess the transformation of ecosystems in the gradient of hemeroby. Species of soil macrofauna react differently to hemeroby, and among them can be distinguished sensitive (ahemerobic), moderately sensitive (mesohemerobic) and resistant (alpha-euhemerobic) to this factor. The different proportions of these species are characteristic of different levels of hemeroby, which can be indicated by the soil macrofauna. Hemeroby is a factor of direct action on soil animals, and its action is mediated by the influence on soil and climatic regimes. Increase of soil hardness and disturbance of the litter layer, deterioration of aeration regime and soil fertility indicators are associated with increase of hemeroby, which can also be indicated by the soil macrofauna.

\section{References}

Acosta, A., Blasi, C., Carranza, M. L., Ricotta, C., \& Stanisci, A. (2003). Quantifying ecological mosaic connectivity and hemeroby with a new topoecological index. Phytocoenologia, 33(4), 623-631.

Andreeva, R. V. (1990). Opredelitel' lichinok slepnej [Identification key to the horsefly larvae e]. Naukova Dumka, Kyiv (in Russian).

Angermeier, P. L. (2000). The natural imperative for biological conservation. Conservation Biology, 14(2), 373-381.

Aronson, M. F. J., La Sorte, F. A., Nilon, C. H., Katti, M., Goddard, M. A., Lepczyk, C. A., Warren, P. S., Williams, N. S. G., Cilliers, S., Clarkson, B., Dobbs, C., Dolan, R., Hedblom, M., Klotz, S., Kooijmans, J. L., Kühn, I., Macgregor-Fors, I., Mcdonnell, M., Mörtberg, U., \& Winter, M. (2014). A global analysis of the impacts of urbanization on bird and plant diversity reveals key anthropogenic drivers. Proceedings of the Royal Society B: Biological Sciences, 281(1780), 20133330.

Austin, M. (1999). The potential contribution of vegetation ecology to biodiversity research. Ecography, 22, 465-484.

Austin, M. P. (1987). Models for the analysis of species' response to environmenttal gradients. Vegetatio, 69, 35-45.

Battisti, C., \& Fanelli, G. (2016). Applying indicators of disturbance from plant ecology to vertebrates: The hemeroby of bird species. Ecological Indicators, 61, 799-805.

Battisti, C., Poeta, G., \& Fanelli, G. (2016). The disturbance regime. In: Environmental Science and Engineering (Subseries: Environmental Science). Springer, Berlin, Heidelberg. Pp. 31-46.

Bettez, N. D., \& Groffman, P. M. (2013). Nitrogen deposition in and near an urban ecosystem. Environmental Science and Technology, 47(11), 6047-6051.

Bogyó, D., Magura, T., Simon, E., \& Tóthmérész, B. (2015). Millipede (Diplopoda) assemblages alter drastically by urbanisation. Landscape and Urban Planning, 133, 118-126.

Bonato, L., Minelli, A., Lopresti, M., \& Cerretti, P. (2014). ChiloKey, an interactive identification tool for the geophilomorph centipedes of Europe (Chilopoda, Geophilomorpha). ZooKeys, 443, 1-9.

Borcard, D., Legendre, P., \& Drapeau, P. (1992). Partialling out the spatial component of ecological variation. Ecology, 73(3), 1045-1055.

Borges, P. A. V., Aguiar, C., Amaral, J., Amorim, I. R., André, G., Arraiol, A., Baz, A., Dinis, F., Enghoff, H., Gaspar, C., Ilharco, F., Mahnert, V., Melo, C., Pereira, F., Quartau, J. A., Ribeiro, S. P., Ribes, J., Serrano, A. R. M., Sousa, A. B., \& Wunderlich, J. (2005). Ranking protected areas in the Azores using standardised sampling of soil epigean arthropods. Biodiversity and Conservation, 14(9), 2029-2060.

Borhidi, A. (1995). Social behaviour types, the naturalness and relative ecological indicator values of the higher plants in the Hungarian flora. Acta Botanica Hungarica, 39, 97-181.

Bouché, M. B., \& Al-Addan, F. (1997). Earthworms, water infiltration and soil stability: Some new assessments. Soil Biology and Biochemistry, 29(3-4), $441-452$.

Bray, N., \& Wickings, K. (2019). The roles of invertebrates in the urban soil microbiome. Frontiers in Ecology and Evolution, 7, 359.

Brygadyrenko, V. V. (2015). Influence of tree crown density and density of the herbaceous layer on the structure of litter macrofauna of deciduous forests of Ukraine's steppe zone. Visnyk of Dnipropetrovsk University, Biology, Ecology, 23(2), 134-148.

Brygadyrenko, V. V. (2016). Influence of litter thickness on the structure of litter macrofauna of deciduous forests of Ukraine's steppe zone. Visnyk of Dnipropetrovsk University, Biology, Ecology, 24(1), 240-248.

Büchi, L., \& Vuilleumier, S. (2014). Coexistence of specialist and generalist species is shaped by dispersal and environmental factors. American Naturalist, 183(5), 612-624

Burnham, K. P., \& Anderson, D. R. (2002). Model selection and multimodel inference: A practical information-theoretic approach. Springer, Berlin.

Butenko, K. O., Gongalsky, K. B., Korobushkin, D. I., Ekschmitt, K., \& Zaitsev, A. S. (2017). Forest fires alter the trophic structure of soil nematode communities. Soil Biology and Biochemistry, 109, 107-117.

Buzuk, G. N. (2017). Phytoindication with ecological scales and regression analysis: Environmental index. Bulletin of Pharmacy, 76, 31-37.

Byrne, L. B., Bruns, M. A., \& Kim, K. C. (2008). Ecosystem properties of urban land covers at the aboveground-belowground interface. Ecosystems, 11(7), 1065-1077.

Byrne, L., \& Bruns, M. (2004). The effects of lawn management on soil microarthropods. Journal of Agricultural and Urban Entomology, 21, 151-156.

Capowiez, Y., Sammartino, S., \& Michel, E. (2014). Burrow systems of endogeic earthworms: Effects of earthworm abundance and consequences for soil water infiltration. Pedobiologia, 57(4-6), 303-309.

Carreiro, M. M., \& Tripler, C. E. (2005). Forest remnants along urban-rural gradients: Examining their potential for global change research. Ecosystems, $8(5), 568-582$. 
Chen, G., Li, X., Liu, X., Chen, Y., Liang, X., Leng, J., Xu, X., Liao, W., Qiu, Y. Wu, Q., \& Huang, K. (2020). Global projections of future urban land expansion under shared socioeconomic pathways. Nature Communications, 11(1), 1-12.

Cherny, N. G., \& Golovach, S. J. (1993). Dvuparnonogie mnogonozhki ravninnoj territorii Ukrainy [Millipedes of the plain territory of Ukraine]. Naukova Dumka, Kyiv (in Russian)

Collins, J., Kinzig, A., Grimm, N., Fagan, W. F., Hope, D., Wu, J., \& Borer, E. T. (2000). A new urban ecology. American Scientist, 88(5), 416-425.

Connell, J. H. (1978). Diversity in tropical rain forests and coral reefs. Science, 199, 1302-1310

Croci, S., Butet, A., Georges, A., Aguejdad, R., \& Clergeau, P. (2008). Small urban woodlands as biodiversity conservation hot-spot: A multi-taxon approach. Landscape Ecology, 23(10), 1171-1186.

Decina, S. M., Ponette-González, A. G., \& Rindy, J. E. (2020). Urban tree canopy effects on water quality via inputs to the urban ground surface. In: Levia, D., Carlyle-Moses, D., Iida, S., Michalzik, B., Nanko, K., \& Tischer, A. (Eds.). Forest-water interactions. Ecological studies (analysis and synthesis). Springer, Cham. Vol. 240. Pp. 433-457.

Decina, S. M., Templer, P. H., \& Hutyra, L. R. (2018). Atmospheric inputs of nitrogen, carbon, and phosphorus across. Earth's Future, 6(2), 134-148.

Deichsel, R. (2006). Species change in an urban setting-ground and rove beetles (Coleoptera: Carabidae and Staphylinidae) in Berlin. Urban Ecosystems, 9(3), 161-178.

Dennis, R. L. H., Hodgson, J. G., Grenyer, R., Shreeve, T. G., \& Roy, D. B. (2004). Host plants and butterfly biology. Do host-plant strategies drive butterfly status? Ecological Entomology, 29(1), 12-26.

Devictor, V., Julliard, R., \& Jiguet, F. (2008). Distribution of specialist and generalist species along spatial gradients of habitat disturbance and fragmentation. Oikos, 117(4), 507-514.

Didukh, Y. P. (2011). The ecological scales for the species of Ukrainian flora and their use in synphytoindication. Phytosociocentre, Kyiv.

Dorendorf, J., Wilken, A., Eschenbach, A., \& Jensen, K. (2015). Urban-induced changes in tree leaf litter accelerate decomposition. Ecological Processes, 4, 1.

Dubinina, Y. Y. (2018). The spatial scaling of impact in edaphic and plant factors on the structuring of the soil macrofauna community. Acta Biologica Sibirica, 4(3), 36.

Dufrêne, M., \& Legendre, P. (1997). Species assemblages and indicator species: The need for a flexible asymmetrical approach. Ecological Monograph, 67(3), 345-366.

Duh, J.-D., Shandas, V., Chang, H., \& George, L. A. (2008). Rates of urbanisation and the resiliency of air and water quality. Science of the Total Environment, 400, 238-256.

Ehlers, W. (1975). Observations on earthworm channels and infiltration on tilled and untilled loess soil. Soil Science, 119(3), 242-249.

Entling, W., Schmidt, M. H., Bacher, S., Brandl, R., \& Nentwig, W. (2007). Niche properties of Central European spiders: Shading, moisture and the evolution of the habitat niche. Global Ecology and Biogeography, 16(4), 440-448.

Epp Schmidt, D. J., Kotze, D. J., Homung, E., Setälä, H., Yesilonis, I., Szlavecz, K. Dombos, M., Pouyat, R., Cilliers, S., Tóth, Z., \& Yarwood, S. (2019). Metagenomics reveals bacterial and archaeal adaptation to urban land-use: $\mathrm{N}$ catabolism, methanogenesis, and nutrient acquisition. Frontiers in Microbiology, 10, 2330.

Epp Schmidt, D. J., Pouyat, R., Szlavecz, K., Setälä, H., Kotze, D. J., Yesilonis, I, Cilliers, S., Hornung, E., Dombos, M., \& Yarwood, S. A. (2017). Urbanization erodes ectomycorrhizal fungal diversity and may cause microbial communities to converge. Nature Ecology and Evolution, 1, 123.

Fanelli, G., Tescarollo, P., \& Testi, A. (2006). Ecological indicators applied to urban and suburban floras. Ecological Indicators, 6(2), 444 457.

Fehrenbach, H., Grahl, B., Giegrich, J., \& Busch, M. (2015). Hemeroby as an impact category indicator for the integration of land use into life cycle (impact) assessment. International Journal of Life Cycle Assessment, 20(11), 1511-1527.

Fernández, C., Acosta, F. J., Abellá, G., López, F., \& Díaz, M. (2002). Complex edge effect fields as additive processes in patches of ecological systems. Ecological Modelling, 149(3), 273-283.

Gan, H., \& Wickings, K. (2017). Soil ecological responses to pest management in golf turf vary with management intensity, pesticide identity, and application program. Agriculture, Ecosystems and Environment, 246, 66-77.

Geri, F., Amici, V., \& Rocchini, D. (2010). Human activity impact on the heterogeneity of a Mediterranean landscape. Applied Geography, 30(3), 370-379.

Gholami, S., Sayad, E., Gebbers, R., Schirrmann, M., Joschko, M., \& Timmer, J. (2016). Spatial analysis of riparian forest soil macrofauna and its relation to abiotic soil properties. Pedobiologia, 59(1-2), 27-36.

Gilyarov, M. S. (1964). Opredelitel' obitayushhikh v pochve lichinok nasekomykh [Identification key of soil-inhabiting insect larvae]. Nauka, Moscow (in Russian).

Godefroid, S., \& Koedam, N. (2007). Urban plant species patterns are highly driven by density and function of built-up areas. Landscape Ecology, 22(8), 1227-1239.

Goncharenko, I. V. (2017). Fitoindykaciya antropogennogo navantazhennya [Phytoindication of anthropogenic factor]. Serednyak T. K., Dnipro (in Ukranian).
Gray, J. S. (1989). Effects of environmental stress on species rich assemblages Biological Journal of the Linnean Society, 37, 19-32.

Griffiths, B., Faber, J., \& Bloem, J. (2018). Applying soil health indicators to encourage sustainable soil use: The transition from scientific study to practical application. Sustainability, 10(9), 3021

Groffman, P. M., Avolio, M., Cavender-Bares, J., Bettez, N. D., Grove, J. M. Hall, S. J., Hobbie, S. E., Larson, K. L., Lerman, S. B., Locke, D. H., Heffernan, J. B., Morse, J. L., Neill, C., Nelson, K. C., O’Neil-Dunne, J., Pataki, D. E., Polsky, C., Chowdhury, R. R. \& Trammell, T. L. E. (2017). Ecological homogenization of residential macrosystems. Nature Ecology and Evolution, 1(7), 1-3.

Groffman, P. M., Cavender-Bares, J., Bettez, N. D., Grove, J. M., Hall, S. J., Heffernan, J. B., Hobbie, S. E., Larson, K. L., Morse, J. L., Neill, C., Nelson, K. O’Neil-Dunne, J., Ogden, L., Pataki, D. E., Polsky, C., Chowdhury, R. R., \& Steele, M. K. (2014). Ecological homogenization of urban USA. Frontiers in Ecology and the Environment, 12(1), 74-81.

Gural-Sverlova, N. V., \& Gural, R. I. (2012). Vyznachnyk nazemnykh molyuskiv Ukrayiny [Identification book of the terrestrial molluscs of Ukraine]. State Museum of Natural History, Lviv (in Ukranian).

Hall, S. J., Learned, J., Ruddell, B., Larson, K. L., Cavender-Bares, J., Bettez, N., Groffman, P. M., Grove, J. M., Heffernan, J. B., Hobbie, S. E., Morse, J. L., Neill, C., Nelson, K. C., O’Neil-Dunne, J. P. M., Ogden, L., Pataki, D. E., Pearse, W. D., Polsky, C., Chowdhury, R. R., \& Trammell, T. L. E. (2016). Convergence of microclimate in residential landscapes across diverse cities in the United States. Landscape Ecology, 31(1), 101-117.

Heegaard, E. (2002). A model for alpine species distribution in relation to snowmelt time and altitude. Journal of Vegetation Science, 13(4), 493-504.

Hill, M. O., Roy, D. B., \& Thompson, K. (2002). Hemeroby, urbanity and ruderality: Bioindicators of disturbance and human impact. Journal of Applied Ecology, 39(5), 708-720.

Hill, T. C. J., Walsh, K. A., Harris, J. A., \& Moffett, B. F. (2003). Using ecological diversity measures with bacterial communities. FEMS Microbiology Ecology, 43(1), 1-11.

Huisman, J., Olff, H., \& Fresco, L. F. M. (1993). A hierarchical set of models for species response analysis. Journal of Vegetation Science, 4(1), 37-46.

Jalas, J. (1955). Hemerobe und Hemerochore Pflanzenarten. Ein Terminologischer Reformversuch. Acta Societas Flora Fauna Fennica, 72, 1-15.

Jansen, F., \& Oksanen, J. (2013). How to model species responses along ecological gradients - Huisman-Olff-Fresco models revisited. Journal of Vegetation Science, 24(6), 1108-1117.

Jia, Z., Li, S., \& Wang, L. (2018). Assessment of soil heavy metals for eco-environment and human health in a rapidly urbanization area of the upper Yangtze Basin. Scientific Reports, 8(1), 1-14

Joimel, S., Cortet, J., Jolivet, C. C., Saby, N. P. A., Chenot, E. D., Branchu, P., Consalès, J. N., Lefort, C., Morel, J. L., \& Schwartz, C. (2016). Physico-chemical characteristics of topsoil for contrasted forest, agricultural, urban and industrial and uses in France. Science of the Total Environment, 545-546, 40-47.

Joimel, S., Schwartz, C., Hedde, M., Kiyota, S., Krogh, P. H., Nahmani, J., Pérès, G., Vergnes, A., \& Cortet, J. (2017). Urban and industrial land uses have a higher soil biological quality than expected from physicochemical quality. Science of the Total Environment, 584-585, 614-621.

Jones, E. L., \& Leather, S. R. (2012). Invertebrates in urban areas: A review. European Journal of Entomology, 109(4), 463-478.

Jouquet, P., Podwojewski, P., Bottinelli, N., Mathieu, J., Ricoy, M., Orange, D. Tran, T. D., \& Valentin, C. (2008). Above-ground earthworm casts affect water runoff and soil erosion in Northern Vietnam. Catena, 74(1), 13-21.

Julliard, R., Clavel, J., Devictor, V., Jiguet, F., \& Couvet, D. (2006). Spatial segregation of specialists and generalists in bird communities. Ecology Letters, 9(11), 1237-1244.

Kabakov, O. N. (2006). Plastinchatousye zhuki podsemejstva Scarabaeinae (Coleoptera: Scarabaeidae) fauny Rossii i sopredelnykh stran [Scarab beetles of the subfamily Scarabaeinae (Coleoptera: Scarabaeidae) of Russia and adjacent countries]. KMK, Moscow (in Russian)

Katayama, N., Amano, T., Naoe, S., Yamakita, T., Komatsu, I, Takagawa, S., Sato, N., Ueta, M., \& Miyashita, T. (2014). Landscape heterogeneity - biodiversity relationship: Effect of range size. PLoS One, 9(3), e93359.

Knop, E. (2016). Biotic homogenization of three insect groups due to urbanization. Global Change Biology, 22(1), 228-236.

Komaromi, N. A., Nikolenko, N. Y., \& Puchkov, A. V. (2019). The faunistic structure of beetles (Insecta: Coleoptera) in herpetobios of urbocenosis of Kharkiv city (Ukraine). Ukrainian Entomological Journal, 15(2), 3-21.

Kowarik, I. (1990). Some responses of flora and vegetation to urbanization in Central Europe. In: Sukopp, H., Hejny, S., \& Kowarik, I. (Eds.). Plants and plant communities in the urban environment. SPB Academic Publishing, The Hague. Pp. 45-74.

Kowarik, I. (2020). Herbert Sukopp - an inspiring pioneer in the field of urban ecology. Urban Ecosystems, 23, 1-11. 
Krivolutsky, D. A. (1992). Pochvennaya fauna v ekologicheskom kontrole [Soil fauna in ecological control]. Nauka, Moscow (in Russian).

Krivosheina, M. G. (2012). Identification book of the families and genera of Palaearctic dipteran insects of the suborder Nematocera, based on larvae. KMK, Moscow.

Kryzhanovsky, O. L. (1964). Carabidae - Zhuzheliczy [Carabidae - ground beetles]. In: Bey-Bienko, G. A. (Ed.). Opredelitel' nasekomykh evropejskoj chasti SSSR. Tom 2. Zhestkokrylye i veerokrylye [Insects of the European part of the USSR Vol. 5. Coleoptera and Strepsiptera]. Nauka, Moscow. Pp. 23-68 (in Russian).

Kunah, O. N., Zhukov, O. V., \& Pahomov, A. Y. (2010). Morfologiya doshhovykh cherv'yakiv (Lumbricidae) [Earthworm morphology (Lumbricidae)] DNU University Press, Dnipropetrovsk (in Ukranian).

Kunakh, O. N., Kramarenko, S. S., Zhukov, A. V., Kramarenko, A. S., \& Yorkina N. V. (2018). Fitting competing models and evaluation of model parameters of the abundance distribution of the land snail Vallonia pulchella (Pulmonata, Valloniidae). Regulatory Mechanisms in Biosystems, 9(2), 198-202.

Kunakh, O., \& Kovalenko, D. (2019). Fitting competing models of the population abundance distribution: Land snails from Nikopol Manganese Ore Basin Technosols. Ekologia Bratislava, 38(4), 367-381.

Lavelle, P., Senapati, B., \& Barros, E. (2003). Soil macrofauna. In: Schroth, G., \& Sinclair, F. L. (Eds.). Trees, crops and soil fertility: Concepts and research methods. CAB International, Wallingford. Pp. 303-323.

Legendre, P., \& Birks, H. J. B. (2012). From classical to canonical ordination. In: Birks, H. J. B., Lotter, A. F., Juggins, S., \& Smol, J. P. (Eds.). Tracking environmental change using lake sediments: Data handling and numerical techniques. Springer, Dordrecht. Pp. 201-248.

Legendre, P., \& Gallagher, E. D. (2001). Ecologically meaningful transformations for ordination of species data. Oecologia, 129(2), 271-280.

Li, N., Chu, H., Qi, Y., Li, C., Ping, X., Sun, Y., \& Jiang, Z. (2019). Alpha and beta diversity of birds along elevational vegetation zones on the southern slope of Altai Mountains: Implication for conservation. Global Ecology and Conservation, 19, e643.

Lizée, M. H., Mauffrey, J. F., Tatoni, T., \& Deschamps-Cottin, M. (2011). Monitoring urban environments on the basis of biological traits. Ecological Indicators, 11(2), 353-361.

Lo, F. C., \& Marcotullio, P. J. (2000). Globalisation and urban transformations in the Asia-Pacific region: A review. Urban Studies, 37(1), 77-111.

Magura, T., Lövei, G. L., \& Tóthmérész, B. (2010). Does urbanization decrease diversity in ground beetle (Carabidae) assemblages? Global Ecology and Biogeography, 19(1), 16-26.

Magura, T., Nagy, D., \& Tóthmérész, B. (2013). Rove beetles respond heterogeneously to urbanization. Journal of Insect Conservation, 17(4), 715-724.

Marcotullio, P. J., Braimoh, A. K., \& Onishi, T. (2008). The impact of urbanization on soils. In: Braimoh, A. K., \& Vlek, P. L. G. (Eds.). Land use and soil resources. Springer, Dordrecht. Pp. 201-250.

Martinez, N. G., Bettez, N. D., \& Groffman, P. M. (2014). Sources of variation in home lawn soil nitrogen dynamics. Journal of Environmental Quality, 43(6), 2146-2151.

Mathieu, J., Rossi, J. P., Grimaldi, M., Mora, P., Lavelle, P., \& Rouland, C. (2004) A multi-scale study of soil macrofauna biodiversity in Amazonian pastures. Biology and Fertility of Soils, 40(5), 300-305.

McCabe, D. J., \& Gotelli, N. J. (2000). Effects of disturbance frequency, intensity, and area on assemblages of stream macroinvertebrates. Oecologia, 124(2), 270-279.

McDonnell, M. J., \& Pickett, S. T. A. (1990). Ecosystem structure and function along urban-rural gradients: An unexploited opportunity for ecology. Ecology, 71(4), 1232-1237.

McDonnell, M., Pickett, S., Groffman, P., Bohlen, P., Pouyat, R., Zipperer, W. Parmelee, R., Carreiro, M., \& Medley, K. (1997). Ecosystem processes along an urban-to-rural gradient. Urban Ecosystems, 1(1), 21-36.

Mcintyre, N. E., Knowles-Yánez, K., \& Hope, D. (2000). Urban ecology as an interdisciplinary field: Differences in the use of "urban" between the social and natural sciences. Urban Ecosystems, 4(1), 5-24

McKinney, M. L. (2006). Urbanization as a major cause of biotic homogenization. Biological Conservation, 127(3), 247-260.

Melliger, R. L., Rusterholz, H. P., \& Baur, B. (2017). Ecosystem functioning in cities: Combined effects of urbanisation and forest size on early-stage leaf litter decomposition of European beech (Fagus sylvatica L.). Urban Forestry and Urban Greening, 28, 88-96.

Michaelis, J., \& Diekmann, M. R. (2017). Biased niches - Species response curves and niche attributes from Huisman-Olff-Fresco models change with differing species prevalence and frequency. PLoS One, 12(8), 1-16.

Minchin, P. R. (1987). An evaluation of the relative robustness of techniques for ecological ordination. Vegetatio, 69, 89-107.

Montalvo, J., Ruiz-Labrador, E., Montoya-Bernabéu, P., \& Acosta-Gallo, B. (2019). Rural-urban gradients and human population dynamics. Sustainability, 11(11), 3107.
Mouillot, D., Graham, N. A. J., Villéger, S., Mason, N. W. H., \& Bellwood, D. R (2013). A functional approach reveals community responses to disturbances. Trends in Ecology and Evolution, 28(3), 167-177.

Murata, T., \& Kawai, N. (2018). Degradation of the urban ecosystem function due to soil sealing: Involvement in the heat island phenomenon and hydrologic cycle in the Tokyo metropolitan area. Soil Science and Plant Nutrition, 64(2), 145-155.

Nagy, D. D., Magura, T., Horváth, R., Debnár, Z., \& Tóthmérész, B. (2018). Arthropod assemblages and functional responses along an urbanization gradient: A traitbased multi-taxa approach. Urban Forestry and Urban Greening, 30, 157-168.

Nahmani, J., \& Lavelle, P. (2002). Effects of heavy metal pollution on soil macrofauna in a grassland of Northern France. European Journal of Soil Biology, 38(3-4), 297-300.

Nemergut, D. R., Schmidt, S. S. K., Fukami, T., O’Neill, S. P., Bilinski, T. M., Stanish, L. F., Knelman, J. E., Darcy, J. L., Lynch, R. C., Wickey, P., Ferrenberg, S., Zhao, S., Qiu, S. S. L., Cao, C., Zheng, C., Zhou, W., He, P., Wang, J. J., Li, X. Y., \& Gallagher, E. D. (2014). Soil type is the primary determinant of the composition of the total and active bacterial communities in arable soils. Soil Biology and Biochemistry, 8(3), 1-8.

Niemelä, J. (1999). Ecology and urban planning. Biodiversity and Conservation, $8(1), 119-131$

Niemelä, J., \& Kotze, D. J. (2009). Carabid beetle assemblages along urban to rural gradients: A review. Landscape and Urban Planning, 92(2), 65-71.

Niemelä, J., Kotze, D. J., Venn, S., Penev, L., Stoyanov, I., Spence, J., Hartley, D., \& Montes de Oca, E. (2002). Carabid beetle assemblages (Coleoptera, Carabidae) across urban-rural gradients: An international comparison. Landscape Ecology, 17(5), 387-401.

Niemelä, J., Kotze, J., Ashworth, A., Brandmayr, P., Desender, K., New, T., Penev, L., Samways, M., \& Spence, J. (2000). The search for common anthropogenic impacts on biodiversity: A global network. Journal of Insect Conservation, 4(1), 3-9.

Oksanen, J., Blanchet, F. G., Kindt, R., Legendre, P., Minchin, P. R., O’Hara R. B., Simpson, G. L., Solymos, P., Stevens, M. H. H., \& Wagner, H. (2018) Community Ecology Package. R package version 2.5-2.

Olden, J. D., Poff, N. L. R. \& McKinney, M. L. (2006). Forecasting faunal and floral homogenization associated with human population geography in North America. Biological Conservation, 127(3), 261-271.

Palmer, M. W. (1993). Putting things in even better order: The advantages of canonical correspondence analysis. Ecology, 74(8), 2215-2230.

Paoletti, M. G. (1999a). The role of earthworms for assessment of sustainability and as bioindicators. Agriculture, Ecosystems and Environment, 74(1-3), 137-155.

Paoletti, M. G. (1999b). Using bioindicators based on biodiversity to assess landscape sustainability. Agriculture, Ecosystems and Environment, 74(1-3), 1-18

Paoletti, M. G., \& Hassall, M. (1999). Woodlice (Isopoda: Oniscidea): Their potential for assessing sustainability and use as bioindicators. Agriculture, Ecosystems and Environment, 74(1-3), 157-165.

Paoletti, M. G., Osler, G. H. R., Kinnear, A., Black, D. G., Thomson, L. J., Tsitsilas, A., Sharley, D., Judd, S., Neville, P., \& D'Inca, A. (2007). Detritivores as indicators of landscape stress and soil degradation. Australian Journal of Experimental Agriculture, 47(4), 412.

Paoletti, M., \& Bressan, M. (1996). Soil invertebrates as bioindicators of human disturbance. Critical Reviews in Plant Sciences, 15(1), 21-62.

Pavao-Zuckerman, M. A. (2008). The nature of urban soils and their role in ecological restoration in cities. Restoration Ecology, 16(4), 642-649.

Pavao-Zuckerman, M. A., \& Coleman, D. C. (2007). Urbanization alters the functional composition, but not taxonomic diversity, of the soil nematode community. Applied Soil Ecology, 35(2), 329-339.

Peck, D. C. (2009). Comparative impacts of white grub (Coleoptera: Scarabaeidae) control products on the abundance of non-target soil-active arthropods in turforass. Pedobiologia, 52(5), 287-299.

Perel, T. S. (1979). Rasprostranenie i zakonomernosti raspredeleniya dozhdevykh chervej fauny SSSR [Spread and regularity of the distribution of the earthworms of the USSR fauna]. Nauka, Moscow (in Russian).

Pey, B., Nahmani, J., Auclerc, A., Capowiez, Y., Cluzeau, D., Cortet, J. Ô., Decaëns, T., Deharveng, L., Dubs, F., Joimel, S., Briard, C., Grumiaux, F., Laporte, M. A., Pasquet, A., Pelosi, C., Pernin, C., Ponge, J. F., Salmon, S., Santorufo, L., \& Hedde, M. (2014). Current use of and future needs for soil invertebrate functional traits in community ecology. Basic and Applied Ecology, 15(3), 194-206.

Pouyat, R. V, Russell-Anem, J., Yesilonis, I. D., \& Groffman, P. M. (2003). Soil carbon in urban forest ecosystems. In: Kimble, J. M., Lal, R., Birdsey, R., \& Heath, L. S. (Eds.). The potential of U.S. forest soils to sequester carbon and mitigate the greenhouse effect. CRC Press, Boca Raton. Pp. 347-362.

Pouyat, R. V., \& Carreiro, M. M. (2003). Controls on mass loss and nitrogen dynamics of oak leaf litter along an urban-rural land-use gradient. Oecologia, 135(2), 288-298.

Pouyat, R. V., Setälä, H., Szlavecz, K., Yesilonis, I. D., Cilliers, S., Hornung, E., Yarwood, S., Kotze, D. J., Dombos, M., McGuire, M. P., \& Whitlow, T. H. (2017). Introducing GLUSEEN: A new open access and experimental network in urban soil ecology. Journal of Urban Ecology, 3(1), jux002. 
Pouyat, R. V., Szlavecz, K., Yesilonis, I. D., Wong, C. P., Murawski, L., Marra, P., Casey, R. E., \& Lev, S. (2015). Multi-scale assessment of metal contamination in residential soil and soil fauna: A case study in the Baltimore-Washington metropolitan region, USA. Landscape and Urban Planning, 142, 7-17.

Pouyat, R. V., Yesilonis, I. D., Dombos, M., Szlavecz, K., Setälä, H., Cilliers, S., Hornung, E., Kotze, D. J., \& Yarwood, S. (2015). A global comparison of surface soil characteristics across five cities: A test of the urban ecosystem convergence hypothesis. Soil Science, 180(4-5), 136-145.

Putchkov, A. V., Brygadyrenko, V. V., \& Markina, T. Y. (2019). Ground beetles of the tribe Carabini (Coleoptra, Carabidae) in the main megapolises of Ukraine. Vestnik Zoologii, 53(1), 3-12.

Rebele, F. (1994). Urban ecology and special features of urban ecosystems. Global Ecology and Biogeography Letters, 4(6), 173-187.

Reif, J., Marhoul, P., \& Koptík, J. (2013). Bird communities in habitats along a successional gradient: Divergent patterns of species richness, specialization and threat. Basic and Applied Ecology, 14(5), 423-431.

Rochefort, S., Therrien, F., Shetlar, D. J., \& Brodeur, J. (2006). Species diversity and seasonal abundance of Collembola in turfgrass ecosystems of North America. Pedobiologia, 50(1), 61-68.

Roxburgh, S. H., Shea, K., \& Wilson, J. B. (2004). The intermediate disturbance hypothesis: Patch dynamics and mechanisms of species coexistence. Ecology, 85(2), 359-371

Salminen, J., van Gestel, C. A. M., \& Oksanen, J. (2001). Pollution-induced community tolerance and functional redundancy in a decomposer food web in metalstressed soil. Environmental Toxicology and Chemistry, 20(10), 2287-2295.

Santorufo, L., Van Gestel, C. A. M., Rocco, A., \& Maisto, G. (2012). Soil invertebrates as bioindicators of urban soil quality. Environmental Pollution, 161, 57-63.

Schleupner, C., \& Link, P. M. (2008). Potential impacts on important bird habitats in Eiderstedt (Schleswig-Holstein) caused by agricultural land use changes. Applied Geography, 28(4), 237-247.

Schleupner, C., \& Schneider, U. A. (2013). Allocation of European wetland restoration options for systematic conservation planning. Land Use Policy, 30(1), 604-614.

Schmolzer, K. (1965). Ordnung Isopoda (Landasseln), Liferung 4, 5. AkademieVerlag, Berlin.

Schrader, S., \& Böning, M. (2006). Soil formation on green roofs and its contribution to urban biodiversity with emphasis on Collembolans. Pedobiologia, $50(4), 347-356$

Schwartz, M. W., Thorne, J. H., \& Viers, J. H. (2006). Biotic homogenization of the California flora in urban and urbanizing regions. Biological Conservation, 127(3), 282-291.

Shaw, E. A., Boot, C. M., Moore, J. C., Wall, D. H., \& Baron, J. S. (2019). Longterm nitrogen addition shifts the soil nematode community to bacterivoredominated and reduces its ecological maturity in a subalpine forest. Soil Biology and Biochemistry, 130, 177-184.

Shi, G., Shan, J., Ding, L., Ye, P., Li, Y., \& Jiang, N. (2019). Urban road network expansion and its driving variables: A case study of Nanjing city. International Journal of Environmental Research and Public Health, 16(13), 2318.

Simon, E., Braun, M., Vidic, A., Bogyó, D., Fábián, I., \& Tóthmérész, B. (2011). Air pollution assessment based on elemental concentration of leaves tissue and foliage dust along an urbanization gradient in Vienna. Environmental Pollution, 159(5), 1229-1233.

Simon, E., Puky, M., Braun, M., \& Tóthmérész, B. (2012). Assessment of the effects of urbanization on trace elements of toe bones. Environmental Monitoring and Assessment, 184(9), 5749-5754.

Simon, E., Vidic, A., Braun, M., Fábián, I., \& Tóthmérész, B. (2013). Trace element concentrations in soils along urbanization gradients in the city of Wien, Austria Environmental Science and Pollution Research, 20(2), 917-924.

Smart, S. M., Thompson, K., Marrs, R. H., Le Duc, M. G., Maskell, L. C., \& Firbank, L. G. (2006). Biotic homogenization and changes in species diversity across human-modified ecosystems. Proceedings of the Royal Society B: Biological Sciences, 273(1601), 2659-2665.

Smetak, K. M., Johnson-Maynard, J. L., \& Lloyd, J. E. (2007). Earthworm population density and diversity in different-aged urban systems. Applied Soil Ecology, 37(1-2), 161-168.

Smith, J., Chapman, A., \& Eggleton, P. (2006). Baseline biodiversity surveys of the soil macrofauna of London's green spaces. Urban Ecosystems, 9(4), 337-349.

Sousa, W. P. (1984). The role of disturbance in natural communities. Annual Review of Ecology and Systematics, 15, 353-391.

Souty-Grosset, C., Badenhausser, I., Reynolds, J. D., \& Morel, A. (2005). Investigations on the potential of woodlice as bioindicators of grassland habitat quality. European Journal of Soil Biology, 41(3-4), 109-116.

Steinhardt, U., Herzog, F., Lausch, A., Miller, E., \& Lehmann, S. (1999). Hemeroby index for landscape monitoring and evaluation. In: Pykh, Y. A. (Ed.). Environmental indices - system analysis approach. EOLSS Publishing, Oxford. Pp. 237-254.

Sukopp, H. (1969). Der Einfluss des Menschen auf die Vegetation. Vegetatio Acta Geobotanica, 17(1), 360-371. ter Braak, C. J. F., \& Looman, C. W. N. (1986). Weighted averaging, logistic regression and the Gaussian response model. Vegetatio, 65(1), 3-11.

ter Braak, C. J. F., \& Prentice, I. C. (1988). A theory of gradient analysis. Advances in Ecological Research, 18(C), 271-317.

ter Braak, C. J. F., \& Šmilauer, P. (2015). Topics in constrained and unconstrained ordination. Plant Ecology, 216(5), 683-696.

Testi, A., Bisceglie, S., Guidotti, S., \& Fanelli, G. (2009). Detecting river environmental quality through plant and macroinvertebrate bioindicators in the Aniene River (Central Italy). Aquatic Ecology, 43(2), 477-486.

Tian, Y., Liu, B., Hu, Y., Xu, Q., Qu, M., \& Xu, D. (2020). Spatio-temporal landuse changes and the response in landscape pattern to hemeroby in a resourcebased city. ISPRS International Journal of Geo-Information, 9(1), 20

Tóth, Z., \& Hornung, E. (2019). Taxonomic and functional response of millipedes (Diplopoda) to urban soil disturbance in a metropolitan area. Insects, 11(1), 25.

Tóth, Z., Szlavecz, K., Epp Schmidt, D. J., Hornung, E., Setälä, H., Yesilonis, I. D., Kotze, D. J., Dombos, M., Pouyat, R., Mishra, S., Cilliers, S., Yarwood, S., \& Csuzdi, C. (2020). Earthworm assemblages in urban habitats across biogeographical regions. Applied Soil Ecology, 151, in press.

Trammell, T. L. E., Pataki, D. E., Pouyat, R. V., Groffman, P. M., Rosier, C., Bettez, N., Cavender-Bares, J., Grove, M. J., Hall, S. J., Heffernan, J., Hobbie, S. E., Morse, J. L., Neill, C., \& Steele, M. (2019). Urban soil carbon and nitrogen converge at a continental scale. Ecological Monographs, 90(2), e01401.

Tuf, I. H., \& Tufova, J. (2008). Proposal of ecological classification of centipede, millipede and terrestrial isopod faunas for evaluation of habitat quality in Czech Republic. Časopis Slezského Zemského Muzea, Série A, Vědy Př́rodní, 57, 37-44.

Turbé, A., De Toni, A., Benito, P., Lavelle, P., Lavelle, P., Ruiz, N., Van der Putten, W. H., Labouze, E., \& Mudgal, S., (2010). Soil biodiversity: Functions, threaths and tools for policy makers. In: Bio Intelligence Service, IRD, and NIOO, Report for European Commission, DG Environment.

van Rensburg, B. J., Peacock, D. S., \& Robertson, M. P. (2009). Biotic homogenization and alien bird species along an urban gradient in South Africa. Landscape and Urban Planning, 92, 233-241.

Vergnes, A., Le Viol, I., \& Clergeau, P. (2012). Green corridors in urban landscapes affect the arthropod communities of domestic gardens. Biological Conservation, 145(1), 171-178

Wall, D. H., Nielsen, U. N., \& Six, J. (2015). Soil biodiversity and human health Nature, 528(7580), 69-76.

Walz, U., \& Stein, C. (2014). Indicators of hemeroby for the monitoring of landscapes in Germany. Journal for Nature Conservation, 22(3), 279-289.

Warren, M. W., \& Zou, X. (2002). Soil macrofauna and litter nutrients in three tropical tree plantations on a disturbed site in Puerto Rico. Forest Ecology and Management, 170(1-3), 161-171.

Wiens, J. A. (1989). The ecology of bird communities. Vol. 1 and 2. Cambridge Studies in Ecology. Cambridge University Press, Cambridge.

Wilson, J. B. (1994). The intermediate disturbance hypothesis of species coexistence is based on patch dynamics. New Zealand Joumal of Ecology, 18(2), 176-181.

Winter, S. (2012). Forest naturalness assessment as a component of biodiversity monitoring and conservation management. Forestry, 85(2), 293-304.

Wood, J. R., Holdaway, R. J., Orwin, K. H., Morse, C., Bonner, K. I., Davis, C., Bolstridge, N., \& Dickie, I. A. (2017). No single driver of biodiversity: Divergent responses of multiple taxa across land use types. Ecosphere, 8(11), e01997.

Yorkina, N., Maslikova, K., Kunah, O., \& Zhukov, O. (2018). Analysis of the spatial organization of Vallonia pulchella (Muller, 1774) ecological niche in Technosols (Nikopol Manganese Ore Basin, Ukraine). Ecologica Montenegrina, $17,29-45$

Yorkina, N., Zhukov, O., \& Chromysheva, O. (2019). Potential possibilities of soi mesofauna usage for biodiagnostics of soil contamination by heavy metals. Ekologia Bratislava, 38(1), 1-10

Zalesskaya, N. T. (1978). Opredelitel' mnogonozhek-kostyanok SSSR [Identification key to Lithobiidae of USSR]. Nauka, Moscow (in Russian)

Zhukov, O. V., Kunah, O. M., Dubinina, Y. Y., \& Novikova, V. O. (2018). The role of edaphic, vegetational and spatial factors in structuring soil animal communities in a floodplain forest of the Dnipro river. Folia Oecologica, 45(1), 8-23.

Zhukov, O. V., Kunah, O. M., Dubinina, Y. Y., Fedushko, M. P., Kotsun, V. I., Zhukova, Y. O., \& Potapenko, O. V. (2019). Tree canopy affects soil macrofauna spatial patterns on broad- and meso-scale levels in an Eastern European poplar-willow forest in the floodplain of the River Dnipro. Folia Oecologica, 46(2), 101-114.

Zhukov, O., Kunah, O., Dubinina, Y., \& Novikova, V. (2018a). The role of edaphic, vegetational and spatial factors in structuring soil animal communities in a floodplain forest of the Dnipro river. Folia Oecologica, 45, 8-23.

Zhukov, O., Kunah, O., Dubinina, Y., \& Novikova, V. (2018b). The role of edaphic and vegetation factors in structuring beta diversity of the soil macrofauna community of the Dnipro river arena terrace. Ekologia Bratislava, 37(3), 301-327. 